NBER WORKING PAPER SERIES

\title{
TEACHER-STUDENT MATCHING AND THE ASSESSMENT OF TEACHER EFFECTIVENESS
}

\author{
Charles T. Clotfelter \\ Helen F. Ladd \\ Jacob L. Vigdor \\ Working Paper 11936 \\ http://www.nber.org/papers/w11936
NATIONAL BUREAU OF ECONOMIC RESEARCH
1050 Massachusetts Avenue
Cambridge, MA 02138
January 2006

Duke University, Box 90245, Durham, NC 27708. We thank Roger Aliaga, Russell Triplett, and Jane Cooley for outstanding research assistance, the Spencer Foundation for financial support, Diane Whitmore and three anonymous referees for valuable comments, and participants in seminars or presentations at the University of Virginia, the University of Michigan, the University of Connecticut, the University of Chicago, Duke University, Harvard University, and the APPAM fall conference for their comments and suggestions. A previous draft of the current paper was entitled, "Teacher Sorting, Teacher Shopping, and the Assessment of Teacher Effectiveness". The views expressed herein are those of the author(s) and do not necessarily reflect the views of the National Bureau of Economic Research.

(C2006 by Charles T. Clotfelter, Helen F. Ladd and Jacob L. Vigdor. All rights reserved. Short sections of text, not to exceed two paragraphs, may be quoted without explicit permission provided that full credit, including (C) notice, is given to the source. 
Teacher-Student Matching and the Assessment of Teacher Effectiveness

Charles T. Clotfelter, Helen F. Ladd and Jacob L. Vigdor

NBER Working Paper No. 11936

January 2006

JEL No. I2, J4

\begin{abstract}
We use administrative data on North Carolina public schools to document the tendency for more highly qualified teachers to be matched with more advantaged students, and we measure the bias this pattern generates in estimates of the impacts of various teacher qualifications on student achievement. One of the strategies we use to minimize this bias is to restrict the analysis to schools that assign students to classrooms in a manner statistically indistinguishable from random assignment. Using data for 5th grade, we consistently find significant returns to teacher experience in both math and reading and to licensure test scores in math achievement. We also find that the returns in math are greater for socioeconomically advantaged students, a finding that may help explain why the observed form of teacher-student matching persists in equilibrium.

Charles T. Clotfelter

Terry Sanford Institute of Public Policy

Duke University

Box 90245

Durham, NC 27708

and NBER

charles.clotfelter@duke.edu

Helen F. Ladd

Terry Sanford Institute of Public Policy

Duke University

Box 90245

Durham, NC 27708

hladd@duke.edu

Jacob L. Vigdor

Terry Sanford Institute of Public Policy

Duke University

Box 90245

Durham, NC 27708

and NBER

jacob.vigdor@duke.edu
\end{abstract}




\section{Introduction}

Nearly all observers of the education process, including scholars, school administrators, policy-makers, and parents, point to teacher quality as the most significant institutional determinant of academic success. ${ }^{1}$ Considerable uncertainty remains, however, concerning exactly which aspects of teachers are important, whether those aspects can be measured, and whether that effectiveness differs by type of student. Recent studies by Rivkin, Hanushek and Kain (2005), Hanushek, Kain, O’Brien and Rivkin (2005), Ballou, Sanders and Wright (2004), Rockoff (2004), Nye, Konstantopoulos and Hedges (2004) and Aaronson, Barrow and Sander (2003), for example, find evidence of significant across-teacher variation in student test scores, but find little evidence that any observable teacher characteristic, save experience, explains any of this variation.

Estimates of the impact of teacher characteristics in studies like these will be biased in situations where non-random sorting of students and teachers into schools and classrooms introduce correlations between the included characteristics and unobserved determinants of student test scores. ${ }^{2}$ This paper examines the extent to which the non-random matching of teachers to students generated by these sorting processes affects estimates of the relationship between teacher characteristics and student achievement. Our goals are both to provide new

${ }^{1}$ See, for example, Darling-Hammond 2000 and American School Board Journal 1999. That public policy also recognizes the importance of having highly qualified teachers in every classroom is indicated by government regulation at many levels includ ing standard s for highly qualified teachers mandated by the Federal No Child Left Behind Act, state-level licensing requirements, and local hiring practices.

${ }^{2}$ The Nye et al. (2004) study, which uses data from the Tenne ssee STAR experiment, may be immune to this criticism, since it estimates teacher fixed effects within schools where students were assigned to classrooms random ly. There have been a number of criticisms of the ran domization process in the Tenne ssee STA R experim ent, however; see Krueger (1999) for a discussion. See Todd and Wolpin (2003) for a general discussion of omitted variables bias in models of student achievement. 
evidence on this policy-relevant behavior and to illustrate how rich administrative data can be used to approximate the results that would emerge from a random experiment.

We begin by documenting the extent of non-random teacher-student matching, using an administrative data set covering the population of elementary students in the State of North Carolina, which matches most students to their individual classroom teachers. Consistent with previous evidence, we find that teachers with more experience, degrees from more competitive colleges, and advanced degrees tend to teach at schools serving more affluent, higher achieving and whiter populations. We find additional evidence that even within schools, teachers with stronger credentials tend to teach more affluent students. This evidence is consistent with existing research on teacher labor market sorting and parental efforts to secure better resources for their children.

We then examine how the sorting of teachers and students affects estimates of teacher effectiveness. In contrast to some recent studies, which estimate achievement models with teacher fixed effects and then regress the fixed effects on observable characteristics (see, e.g., Nye, Konstantopoulos and Hedges 2004 or Aaronson, Barrow and Sander 2003), we focus on the direct estimation of the relationship between teacher credentials and student outcomes. ${ }^{3}$ Any bias uncovered in our analysis, it should be noted, applies with equal force to models that employ teacher fixed effects.

We employ three strategies to counter the bias that arises from the processes of sorting

\footnotetext{
${ }^{3}$ Ultimately, teacher fixed-effects models are unsatisfying to policy-makers be cause they are observab le only ex post. Identifying important credentials and characteristics is of greater value in this regard. A teacher's characteristics are not the only determinant of a teacher's effectiveness, of course. A more complete measure of teacher quality would require the direct observation of classroom performance in a wide variety of standardized settings or the use of teacher portfolios, both of which are expensive means of gathering information on teaching quality.
} 
that arise across and within schools: the addition of an extended set of student-level control variables, the use of school fixed effects, and the use of a subsample of the schools that feature relatively balanced distributions of students across classrooms, based on observable characteristics. ${ }^{4}$ Our results suggest that the bias from between-school sorting is large; the bias associated with sorting within schools, by contrast, is more limited in nature and may actually vary in sign across subsamples of schools. Ultimately, two characteristics - teacher experience and licensure test scores - emerge as robust determinants of test scores for fifth grade students.

Additional tests for differential effects by type of student provide suggestive evidence that the math score returns to teacher attributes are higher for more advantaged, higher performing students. This finding implies, first, that efforts to increase the math achievement of low-performing students by assigning them more ex perienced teachers could reduce average math test scores, potentially setting the stage for a classic equity-efficiency tradeoff. Second, it provides an additional possible explanation for the observed equilibrium patterns of teacher assignment that favor more advantaged students.

\section{Sorting, non-random matching, and the potential for bias in estimated teacher effects}

The principal empirical strategy used in the economics literature to assess the importance of teachers and teacher characteristics is the estimation of education production functions, which generally take the form:

\footnotetext{
${ }^{4}$ While we cannot prove that assignment is truly random in these schools, any within school sorting of students would have to be uncorrelated with a vector of six student characteristics including measures of past achievement, socioeconomic status, and race. The ratio of selection on unobservables to selection on observables would have to be very high to attribute the results we ob tain to selection (Altonji, Eld er and T aber, 20 02).
} 
(1) $y_{i j t}=\delta y_{i j t-1}+\beta_{1} X_{i t}+\beta_{2} X_{j t}+\epsilon_{i j t}$

where $i$ indexes students, $j$ indexes classrooms, and $t$ indexes time ( Rivkin, Hanushek and Kain, 2005; summaries by Hanushek, 1986, 1997, 2002; Goldhaber and Brewer, 2000; Summers and Wolfe,1977; and Coleman et al., 1966). The dependent variable is a standardized test score. ${ }^{5}$ The lagged test score is typically included in the equation to reflect the cumulative nature of the education process and is intended to pick up the effects of prior year school and family characteristics. The parameter $\delta$ is in many cases constrained to be equal to one. In other cases, such as in studies for which lagged test scores are unavailable or in studies using adult outcomes as the dependent variable, $\delta$ may be constrained to zero. In still other cases, the parameter $\delta$ is estimated explicitly. ${ }^{6}$ The vector $X_{i t}$ measures the characteristics of student $i$ at time $t$, and may contain time-invariant characteristics such as student gender or race. The vector $X_{j t}$ represents measurable school inputs, including class size as well as teacher characteristics. Recent literature has included teacher fixed effects as elements of $X_{j t}$.

Obtaining unbiased estimates of $\beta_{2}$, the marginal effects of school inputs is difficult because parent- or teacher-driven processes of across-school and within-school sorting are likely to lead to a situation in which observable characteristics of students, teachers and classrooms are

\footnotetext{
${ }^{5}$ Although many economists would argue that a more relevant outcome is returns in the labor market (see Card and Kreuger, 1992, and Betts, 1996), achievement test scores have the advantage of being available at the time the education is provided, of being of interest for their own sake, and of being a proxy, albeit imperfect, for future success in the labor market (Ferguson and Ladd, 1996).

${ }^{6}$ Typically o mitted from the standard model are unmeasure d characteristics of students, such as their ability and motivation, that affect achievement. Provided such variables have constant effects on achievement over time and that their effects deteriorate at the same rates as prior achievement, they cancel out in this lagged form of the production function. See Boardman and Murnane (1979) for other assumptions that would generate this particular form of the production function. In an assessment of the econometric issues raised by such models, Todd and $\mathrm{W}$ olpin (2003) argue that the value-adde d versioni of the model $(\delta=1)$ assumes that inputs have the same effects at all grade levels, while the explicitly estimated version (lagged achievement) assumes that the effects of inputs decay over time at a constant rate. Constraining $\delta$ to zero implies that only contemporaneous inputs matter.
} 
correlated with unobserved, and hence omitted, factors related to student and teacher ability or to other factors that positively influence achievement, such as parental involvement. A similar problem arises in models that use teacher fixed effects. ${ }^{7}$

The first such process, which we call across-school sorting, has to do with how teachers and students choose, or are assigned, to schools. As numerous empirical studies have shown, teachers' preferences among districts are influenced by factors such as salary levels and student characteristics, and among schools within districts by the characteristics of the students, with the more qualified teachers often showing both the inclination and ability to transfer to schools with more advantaged students. ${ }^{8}$ At the same time that teachers are making decisions about where to teach, parents are also making decisions that affect how students are distributed across schools. Many of these parental decisions involve the choice of where to live, as in the well-known Tiebout (1956) model. ${ }^{9}$ But in some cases, such as in districts permitting some form of school choice, parents may be able to choose among schools without having to move.

The second major process driving the matching of teachers with students, within-school sorting, has received much less attention in economic models. Parents often form opinions

\footnotetext{
${ }^{7}$ The kind of non-random sorting observed in schools has similarities to job training programs. LaLonde (1986) compares experimental and non-experimental estimation strategies in that latter application.

${ }^{8}$ Empirical studies of teacher moves and quits reve al that teachers a re more like ly to switch schoo ls within a district, move from one district to another, or quit altogether if their original school has a higher percentage of lowachieving, low-income, or minority students or a high student-teacher ratio See New York Public Education Association (1955), Mont and Rees (1996), Freeman, Scafidi and Sjoquist (2002, Tables 10-12), Lankford, Loeb and Wycko ff (2002, T ables 10 and 11), Reed and Rueben (2002). Sieber's (1982, p. 42) study of classro om assignm ents in a New York City elementary school reports that teachers normally "viewed as a rewarding and prestigious task" the assignment to classes with advanced students.

${ }^{9}$ Empirical studies confirm that household residential demand is influenced by perceived school quality and by such school characteristics as racial composition (Bogart and Cromwell 2000).
} 
regarding which of the available teachers in a school they would most prefer to teach their children; some act on these preferences by trying to influence administrative decisions regarding who will teach their child (Hollingshead 1949; Sieber 1982; Lareau 1987 and 2000; Oakes 1995). Although many principals appear to resist such efforts, this kind of "teacher shopping" often seems to be successful (Hui, 2003). Teachers themselves may be an additional source of withinschool sorting. Experienced teachers, for example, may successfully resist being assigned less able students.

If these two processes result in the matching of more able students to teachers with stronger qualifications, a state we refer to as positive matching, coefficients on these qualifications will be biased upward. Available evidence indicates that positive matching of teachers and students is the empirical norm (Rivkin, Hanushek and Kain, 2005; Betts, Zau and Rice 2003; Clotfelter, Ladd and Vigdor 2004)..$^{10}$ The alternative condition - negative matching would occur if teachers with stronger qualifications were assigned to classes with the less able students. ${ }^{11}$ In such a scenario, coefficients on teacher qualifications would be biased downwards.

\section{North Carolina data}

The data we use for this study are derived from administrative records maintained by the

${ }^{10}$ See Clotfelter, Ladd and Vigdor (2004) for a discussion of theoretical rationales for positive matching.

${ }^{11}$ Negative matching might be predicted by a Lazear (2001)-style mod el of an aggre gate achieve mentmaximizing administrator, in the event that the returns to teacher quality are highest for low-p erforming stud ents. Evidence presented below suggest that this condition does not hold, at least for the measure of achievement utilized by North Caro lina public schools. 
North Carolina Education Research Data Center (NCERDC). ${ }^{12}$ North Carolina is an appropriate state for this analysis for several reasons. Because it has a statewide course of study, its tests are closely aligned with what students are expected to know and be able to do. Hence, test scores are likely to measure more fully what teachers have taught than in many other states. The state is relatively large and exhibits substantial variation across its 117 school districts with respect to the racial and socio-economic mix of the students and student performance. Although teachers' associations in North Carolina have no collective bargaining power, cross-district variation in salary schedules, and variation in working conditions across schools, create incentives for teachers to sort in nonrandom ways. Finally, we note that the state boasts a stable and relatively sophisticated performance-based accountability system which could potentially exacerbate the incentives for positive matching (Clotfelter, Ladd, Vigdor, and Aliaga Diaz 2004).

We link several different sets of records to form the database used for this analysis. Student information, including race, gender, participation in the federal free and reduced price lunch subsidy program, and standardized test sc ores are derived from student test records. In addition to these variables, which are available in many administrative data sets, responses to a number of supplemental survey questions, including information on parental education, students' computer use, hours spent watching television, and hours spent reading for leisure at home, as well as a measure of time spent on homework are also available. Each student test score record identifies the name of the teacher who administered the test. In elementary schools, the teacher

\footnotetext{
${ }^{12}$ While these data are not available to the general public, researchers affiliated with academic institutions can apply to the NCERDC, located at Duke University, for access.
} 
administering the test is most likely a student's regular classroom teacher. ${ }^{13}$ By confining our attention to $5^{\text {th }}$ grade students, we are thus able to link the test score database to information on teacher qualifications. As far as we know, North Carolina provides the only state-wide data set that permits the matching of teachers to students at the classroom level.

The teacher data come from a state-maintained archive of personnel records. For each teacher, information is available on licensure test scores, including the type of test taken and the year it was administrated; undergraduate institution attended, whether the teacher has any advanced degrees or is National Board Certified, and the number of years of teaching experience. We formed a standardized licensure test score variable for each teacher by converting test scores from different test administrations in North Carolina to standardized scores using the means and standard deviations for tests taken in each year by all teachers in our data set. ${ }^{14}$ The years of experience variable is the one used by the state to determine a teacher's salary, and generally counts all years of teaching whether in the State of North Carolina, or elsewhere, for which the

\footnotetext{
${ }^{13}$ To verify that a teacher listed as administering a test to students in grade $i$ in school $j$, was actually a classroom teacher in grade $i$ in school $j$, we cross-referenced a separate North Carolina administrative dataset, the School Activity Report, which records the identity and assignment of each teacher in each school. This crossreference eliminates teachers who taught non-core subjects in school $j$ (e.g. music, physical education), those who started positions at the school midyear, and those who had no regular position at the school. Student test score records associated with an "eliminated" teacher are excluded from our analysis. Moreover, since we focus on schools with more than on e classroom per grad e in order to exploit within-school variation in teach er characteristics, students with a valid teacher but in a school with no other valid teachers were also excluded from the sample.

${ }^{14}$ From the early 1960 s through the mid-1990s, all elementary school teachers were required to take either the Elementary Education or the Early Childhood Education test. Starting in the mid-1990s, teachers were required to take both an Eleme natary Education Curriculum and an Elem entary Education Content test. We normalized test scores on each of these tests separately for each year the test was administered based on means and standard deviations from test scores for all teachers in our data set, not just those in our 2001 subset of $5^{\text {th }}$ grade teachers. For teachers with multiple test sc ores in their pe rsonnel file, our teacher test sco re variable e quals the ave rage of all scores for which we can perform this normalization. W hile in principle it would be interesting to enter licensure test scores separately, rather than as a composite, the potential for endogenous choice of test taken on the part of teachers would comp licate any such analysis.
} 
state has given the teacher credit. ${ }^{15}$ Basic demographic information on each teacher, including race and gender, are also available.

Table 1a presents basic summary statistics describing the $5^{\text {th }}$ grade teachers working in North Carolina during the 2000/01 school year, for both the full sample and also the evenly balanced school subsample, to which we will return in section 5 below. The vast majority of the 3,842 individuals matching our definition of a $5^{\text {th }}$ grade teacher were female and white. The median teacher had between six and twelve years of prior experience and fewer than one in ten had no prior experience. The proportion of teachers with licensure test scores within one standard deviation of the mean is slightly more than would be expected with a purely normal distribution (73 percent rather than 68 percent), and the teachers with test scores outside this interval are disproportionately drawn from the lower tail of the distribution. Provided outside opportunities are positively correlated with teacher test scores, this distribution is consistent with a positive correlation between the probability of departure and access to non-teaching opportunities. ${ }^{16}$ Most teachers graduate from colleges ranked by Barron's as being competitive, and more teachers are drawn from the schools at the low end of the college quality spectrum than from the high end. ${ }^{17}$ This pattern reflects the fact that the largest teacher education programs in

\footnotetext{
15 The teacher experience variable was missing for some teachers. In cases where it was possible to observe experience levels in payroll records from other years, we imputed values. In cases where observations from other years' payroll data were inco nsistent with the 2000/01 record., we put more we ight on the mo re recent record. .

${ }^{16}$ Reflecting differences in alternative employment opportunities by teaching field, Murnane and Olsen (1989) show that the length of first spell in teaching varied sig nificantly by teaching area.

17 The categories were derived from information from Barron's College Admissions Selector for 1988, based on information for first-year students in each university in 1986-87. Our category of very competitive includes universities rated as most competitive, highly competitive or very competitive; competitive are those rated as competitive; less competitive are those rated as less competitive or non competitive; and the unranked category includes special progra ms such as art schools, intern ational univer sities or universities for which we we re not able to find a rating. Barron's uses criteria such as the median entrance examination scores, percentages of students scoring
} 
North Carolina are, by state policy, located in the state colleges, which are relatively unselective. Although North Carolina boasts the largest number of National Board Certified teachers in the country, they account for less than 4 percent of the state's fifth grade teachers.

The characteristics of North Carolina's 2000/01 cohort of public school $5^{\text {th }}$ grade students are summarized in Table 1b. Once again, we focus here on the characteristics of the full sample and postpone the discussion of the evenly balanced school subsample to Section 5. Students are more racially diverse than their teachers, and the proportion of black students significantly exceeds the national average. The median student has parents with a high school diploma but no postsecondary degrees, watches between two and three hours of television per day, only rarely uses a personal computer at home, spends 30 minutes per day reading for pleasure, and spends one to three hours on homew ork per day. ${ }^{18}$ Nearly four students in nine are eligible for subsidized lunch; and substantial numbers are rated as exceptional, whether gifted or handicapped. Relatively few students are either repeating the $5^{\text {th }}$ grade or have limited English proficiency.

\section{Evidence of across- and within-school sorting}

As discussed above, in the absence of purposeful intervention on the part of

500 and above and 600 and above on both the math and verbal parts of the SAT or comparable scores for the ACT, percentage of students who ranked in the upper fifth or two-fifths of their high school class, and the percentage of applicants who were accepted. If information for a university was missing for 1988, we substituted the ranking for the 1979 or 1999 Selector, with the choice varying with the era in which the teacher attended college.

18 The information on parental education is based on teacher reports at the time the students are tested. Instead of using the reports of current teachers, we use those of each student's teacher in the prior year. We use these prior year estimates to minimize any bias in our subsequent analyses of the effects of the qualifications of fifth grade teachers on student achievement that could arise from any systematic under or overreporting of parental education correlated with the characteristics of the fifth grade teachers. 
administrators or other officials, theory and previous empirical research suggest that teachers with better credentials will gravitate towards schools with more advantaged students. Table 2 provides evidence of across-school sorting in North Carolina $5^{\text {th }}$ grade classrooms. The rows of the table categorize teachers in five ways, and the columns refer to average characteristics of students at the school level. The table entries are means of these averages, weighted by the number of teachers having the specified qualifications. In all cases higher entries for school characteristics represent higher proportions of more advantaged or higher performing students.

Consistent with the hypothesis of positive matching, the table shows that, by most measures, teachers with better qualifications typically work in schools serving higher proportions of advantaged students. ${ }^{19}$ Teachers with more experience, degrees from more highly ranked colleges, higher licensure test scores, or advanced degrees are more likely to be found in schools with higher proportions of students who are white, not receiving sub sidized lunches, have college educated parents and who scored well on the prior year test. The only non-monotonic patterns appear in the relationships between teacher experience and parent education, and between college rank and percent nonwhite. Nonetheless, the general pattern is clear.

Measures of within-school sorting are shown in Table 3. The rows display the same set of teacher qualifications as those shown in Table 2 and the columns refer to the same student characteristics. The entries, however, now refer to the average characteristics of students at the classroom level relative to the school-wide average. ${ }^{20}$ The clearest patterns emerge for the

\footnotetext{
${ }^{19}$ Using $F$-tests, we were able to reject the hypothesis of equality of student characteristics across teacher qualification categories except in the cell relating teacher experience to percent of students with parents who are college graduates, and in the four cells relating National Board Certification to student characteristics.

${ }^{20}$ In this and subsequent analysis, we restrict our attention to schools with more than one classroom per grade. The mean for each school characteristic in the first three columns is one and in the fourth column is zero.
} 
teachers with the lowest licensure test scores and the teachers who are National Board Certified.

Teachers with the lowest test scores tend to teach in class rooms that have below-average percentages of white students and of students with college-educated parents, and they teach students with less average ability as measured their prior year test scores than those in other classrooms. In contrast, teachers who are National Board Certified teach students who are more affluent, whose parents are more likely to be college graduates, and who are more able than students in other classrooms. Further evidence of this positive matching at the classroom level emerges from the observation that the least experienced teachers tend to teach in classrooms with below-average proportions of students with college educated parents, and teachers who have degrees from the least competitive colleges tend to be in classrooms with the least able students. Thus, the net effect of within-school sorting is qualitatively quite similar to the effect of acrossschool sorting in that it tends to match the most qualified teachers with the most able students.

To investigate the extent of within-school sorting more formally, we conducted a series of $\chi^{2}$ tests using 1,160 North Carolina elementary schools with at least two $5^{\text {th }}$ grade classrooms in 2000/01. We conducted up to six tests in each school to examine whether students' classroom assignments are statistically independent of a set of six student characteristics: gender, race, participation in the Federal subsidized school lunch program, whether the student attended the same school in the previous year, the student's prior year test score (with categories being above or below the state average), and the prior year teacher's report of parental education. ${ }^{21}$ The null hypothesis in each test is that students were assigned randomly across classrooms within the

\footnotetext{
${ }^{21}$ We use d the prior ye ar teacher's re port in ord er to break any potential re lationship be tween the erro rs in the current teacher's estimates of parental educ ation levels and the particular students she teachers.
} 
school with respect to the specified characteristic.

To reduce the probability of incorrectly accepting the null hypothesis, we raised the power of the tests by pooling information on student assignments in the third, fourth, and fifth grades in each school. ${ }^{22}$ We also chose the relatively conservative significance level of 10 percent as the critical value for the tests. Finally, we examine the overall distribution of $p$-values for each set of tests to determine whether the schools that we conclude are assigning students randomly are instead simply presenting insufficient evidence to warrant rejection of the null hypotheses. Were this latter possibility the case, we would expect a skewed overall distribution of $p$-values. Under random assignment, the distribution of $p$-values should be roughly uniform.

As shown in Table 4, in 521 out of the 1,160 schools we failed to reject the null hypothesis of random assignment for all six of our tests. ${ }^{23}$ Figure 1 displays the distribution of $p$ values for the parental education test for all the schools in the sample. The tests for about 6 percent of these schools exhibit $p$-values less that 1 percent, indicating particularly extreme departures from a random distribution of students by parental education. Beyond the 10 percent level, and particularly beyond the 15 percent level, however, the $p$-values display a nearly uniform distribution, with close to 1 percent of all $p$-values in each band of width 0.01 . This

\footnotetext{
${ }^{22}$ In these tests, we compare the actual distribution of students in each classroom to the expected distribution under the hypothesis of even assignment within each grade. In other words, variation in student composition across grades within a school does not increase the size of the chi-squared statistic. Some schools have data or multiple classrooms only for certain grades; for these schools our tests are based only on the grades with adequate data. The previous year test score and previous year attend ance tests use only $4^{\text {th }}$ and $5^{\text {th }}$ grade data, since we have no information on test scores or school attendance prior to $3^{\text {rd }}$ grade.

${ }^{23}$ Under the hypothesis of random assignment, and presuming that the six chi-squared tests are independent, we would expect about 53 percent of schools to fail at least one test, using the 10 percent significance level. Because the student characteristics a re likely to be correlated, however, the chi-squared tes ts are not likely to be independent. As a result, we would expect a lower prop ortion of the schools to fail at lea st one test.
} 
suggests that a relatively small number of schools are responsible for a large share of the systematic sorting made apparent in Table 3.

Figures 2 and 3 show the distributions of $p$-values from the $\chi^{2}$ tests for students by race and subsidized lunch status. The near uniform distribution of the $p$-values for the racial composition test suggests that only a very small fraction of North Carolina schools systematically segregate students by race within schools. At the same time, only a small mass of points emerge with $p$-values very close to one, indicating that few if any schools perfectly balance the racial composition of all classrooms. That pattern is consistent with prior findings of low racial segregation across classrooms within elementary schools (Morgan and McPartland 1981 and Clotfelter, Ladd and Vigdor 2003). The pattern of $p$-values is less uniform for the free and reduced lunch status of students. This measure of student socioeconomic status is actually the strongest predictor of separation across classrooms in North Carolina, yet only a small fraction of schools show evidence of systematic separation by this variable. ${ }^{24}$ We return to the sample of schools that failed none of the six tests in our modeling effort below.

\section{Estimating the effect of teacher qualifications on student achievement}

In principle, the best way to determine the effects of teacher qualifications on student achievement would be to randomly assign teachers with different qualifications to schools and classrooms and to compare the test scores of students facing teachers with different

\footnotetext{
${ }^{24}$ Although it would be interesting to explore the reasons that schools differ in the apparent randomness of their classroom assignments, observable indicators show little relation with assignment patterns. Tables $1 \mathrm{a}$ and $1 \mathrm{~b}$ show that the non-random schools on average have slightly higher shares of black teachers and black, poor, and lowachieving students, comp ared to ap parently rand om schools. Other than these relatively small differences, it is possible only to speculate that, for one reason or another, principals in the non-random schools are simply more open to parental suggestions regarding classroom assignments than are principals in the apparently random schools.
} 
qualifications. The previous section has documented that the actual distribution of teachers in North Carolina is far from random across schools, and that at least some schools systematically assign teachers to classrooms with significantly different characteristics. As a result, the estimation strategy must be more complex and must explicitly account for the nonrandom distribution of teachers. The goal is to approximate the results that would emerge from a truly random experiment.

Our strategy for estimating the effects on teacher qualifications on student achievement in the presence of across-school and within-school sorting has three main components. First is the use of a rich set of student-level control variables that includes both the demographic characteristics of students and their survey responses about the time they spend watching TV, reading and doing homework. To the extent these characteristics are correlated with both achievement and teacher credentials, including them will ameliorate omitted variable bias. Second is the addition of school fixed effects. These fixed effects imply that coefficients are identified on the basis of variation in teacher qualifications across classrooms within each school, eliminating any bias associated with across-school sorting. Third, we restrict the sample to the set of schools that, based on the $\chi^{2}$ tests just discussed, have distributed students across classrooms in a way that balances observable student characteristics. Because any bias associated with nonrandom matching within schools is likely to be most severe in schools that show evidence of a departure from even balancing, restricting the sample in this way will reduce if not eliminate it.

As a benchmark for analyzing the impact of sorting on estimates of teacher credential effects, the first two columns of Table 5 present a very simple descriptive specification. Fifth 
grade math and reading test scores, standardized in each regression to have mean zero and standard deviation one, are estimated as a function solely of teacher characteristics, as well as class size. The absence of control variables means that the estimated effects should be interpreted as associations, not as causal relationships.

The table indicates that many teacher characteristics, including both demographic characteristics and qualifications, exhibit strong and statistically significant partial correlations with student achievement. Relative to white teachers (the omitted racial category) black teachers and teachers of other races teach students with significantly lower test scores. Similarly, relative to female teachers, male teachers teach students with lower math and reading scores. The relationship between student achievement and teacher experience is nonlinear, with the peak occurring in those classrooms with teachers having between 13 and 26 years of experience; novice teachers (the omitted base category) are associated with the lowest test scores. Teachers with degrees from less competitive institutions teach students with significantly lower test scores, and teachers with advanced degrees show a slight but insignificant tendency to teach students with higher test scores. Higher licensure test scores are associated with higher-test scores. Finally, class size is a significant positive predictor of test scores, which could reflect efforts on the part of school administrators to put low-performing students in smaller classes as in Lazear (2001).

The other four regressions in Table 5 reflect the addition of student-level covariates to the basic specification. The third and fourth regressions include controls for student gender, race, subsidized lunch receipt, parental education, time spent watching television, reading for pleasure, 
using a computer, and doing homework, but not for the student's prior year test score. ${ }^{25}$ The addition of these control variables al ters the coefficients of the teacher characteristics in ways that are consistent with the phenomenon of positive matching. The difference between black and white teachers is greatly reduced, and the negative coefficient on teachers of "other race" has been reduced in the equation for reading and reversed in sign for math. The estimated impact of male teachers on reading scores is reduced by two thirds in reading and is indistinguishable from zero for math. The coefficients on the teacher experience variables continue to be largely significant, and the peak continues to occur among highly experienced teachers, but the magnitude of the relationships have declined appreciably. Teachers graduating from less competitive colleges continue to be associated with lower-performance in reading, and those with lower licensure test scores are associated with lower scores in both areas, but the magnitudes of these effects decline as well. Point estimates of class size effects continue to be positive, but the magnitudes are at most one-fifth the level of the initial estimates. ${ }^{26}$

The final pair of regressions in Table 5 adds a single control variable for each student: the student's $4^{\text {th }}$ grade test score. As we noted earlier, lagged test scores are usually included in achievement models to account for the cumulative nature of the education process. When error

\footnotetext{
${ }^{25}$ Because time spent on homework may be endogeno usly determined by teacher behavior, we have also estimated models that exclude the homework variables. The results are similar except that the estimated effects of teacher experience are all somewhat larger than in equations that omit the behavioral variables. Coefficients on student characteristics, derived from the regressions reported in Table 6, appear as Appendix Table A1. Student characteristic coefficients derived from other specifications are available from the authors upon request.

Our sample size declines by roughly 7,000 students in each regression that adds student covariates, owing primarily to missing data on subsidized lunch receipt. Results estimated on a constant set of students across specifications yield qualitatively identical results.

${ }^{26}$ It is worth noting that the addition of student covariates has much the same effect in models with school fixed effects: the model without student covariates exhibits consistently larger estimated teacher effects. The implication is that positive matching within schools is at work, thus imbuing estimated teacher characteristic s with unwarranted impact, owing to omitted variable bias.
} 
terms are serially correlated, however, the inclusion of a lagged dependent variable can lead to biased and inconsistent coefficient estimates, with the sign and magnitude of the bias depending on the direction of serial correlation. ${ }^{27}$

Given certain conditions, however, estimates of the effects of teacher qualifications on student achievement will be unbiased under either specification. The conditions are that the teacher qualifications be uncorrelated with both past values of observable characteristics and the error term, conditional on other observed variables. These conditions would be clearly met if teachers were randomly assigned to students. In such a scenario, teacher credentials are uncorrelated with observed and unobserved student characteristics, both past and present. An empirical test for whether our regression estimates mirror those that would be obtained from a random assignment trial, then, is whether the estimated coefficients are sensitive to the inclusion of a lagged dependent variable. ${ }^{28}$

Comparing the final two columns of Table 5 with the previous two indicates significant differences between models that do or do not include lagged student test scores and, hence, that we have not yet estimated unbiased causal effects of teacher characteristics. For example, the fact that the addition of the lagged dependent achievement variable causes the large negative effect of being a black teacher to disappear provides evidence that the other control variables are

\footnotetext{
${ }^{27}$ The sign of this correlation is unclear a priori. On the one hand, unobserved but relatively permanent characteristics would generate po sitive serial correlation. On the other hand, because standardized tests are noisy signals of ability, some mean reversion is likely to occur which w ould generate negative serial corre lation. Thus, while failure to control for lagged achievement will be expected to generate biased coefficients under any but the most unusual circumstances (namely, when achievement is affected only by contemporaneous school and non-school factors), the inclusion of a lagge d achievem ent variable may introduce bias of its own.

${ }^{28}$ As with tests of over identifying restrictions in instrumental variable estimation, this check focuses on a necessary but not sufficient condition. (Hausman, 1978).
} 
not sufficient to break the correlation between being a black teacher and being assigned to low performing students. Other differences have similar interpetations.

Fortunately, the unusually detailed character of our data, which makes it possible for us to match teachers and students at the classroom level, allows us to incorporate school fixed effects into our achievement regressions (see Table 6). The inclusion of these school fixed effects means that the coefficients of teacher characteristics in that table are estimated based only on the within-school variation in teacher characteristics, thereby eliminating any remaining bias associated with the nonrandom sorting of teachers and students across schools (but not within schools). ${ }^{29}$

Two clear patterns emerge from Table 6. First, introducing school fixed effects drives most of the effects of qualifications down, even relative to the attenuated levels observed in the final columns of Table $5 .{ }^{30}$ Nonetheless many of them remain statistically significant. Second, the two sets of estimates of the effects of teacher qualifications - those from the models with and without the lagged achievement variable - converge. The high degree of concordance of results across specifications gives us confidence that we now have obtained relatively unbiased estimates of the effects of teacher qualifications.

29 There may be some concern that our use of school fixed effects biases estimates of teacher credential effects downwards. Such a bias would occur, for example, if school administrators had access to superior information on teacher quality and hire d teachers of uniform quality. In such a scenario, observed differences in teacher characteristics across classrooms within a school would be offset by opposite differences in unobserved components of quality. While we su spect that such a bias is not likely to be empirically noteworthy, readers with differing opinions may wish to consider our estimates in Tables 6 and 7 as lower bounds for the true effect of teacher credentials on student test scores. The estimates in Table 5 would then serve as upper bounds.

${ }^{30}$ In spite of this evidence, it would not be app ropriate to conclude that the use of scho ol fixed effects obviates the need for including student-level covariates. In unreported specifications including school fixed effects but no student-level covariates, the estimated relationship between most teacher credentials and test scores is more positive than that reported in Table 6 - indicative of omitted variable bias associated with positive within-school matching. 
As displayed in Table 6, statistically significant positive effects on student achievement emerge for teacher experience (for both math and reading), teacher test scores (most clearly for math) and National Board Certification (for reading only). Compared to students assigned to teachers with no prior experience, students assigned to highly experienced teachers attain standardized reading and math test scores roughly one-tenth of a standard deviation higher in math and slightly less than a tenth of a standard deviation in reading. ${ }^{31}$ About half of this gain occurs for the first one or two years of teaching. After that point the experience-test score profile flattens considerably, with the peak occurring in the 20-27 year category in all four specifications. Students assigned to teachers with higher licensure test scores apparently do better in math, but the effect is relatively modest. A one-standard-deviation increase in teacher test score implies at most a 0.017 standard deviation increase in average student math test scores and a somewhat smaller increase in reading scores. Students assigned to National Board Certified teachers score on average $0.030-0.045$ standard deviations higher in reading, but no higher in math. ${ }^{32}$

The estimated impact of the quality of the teacher's college is uniformly small and, in general is not statistically significant. The most surprising result is the consistently negative

\footnotetext{
${ }^{31}$ In a model applying student and school fixed effects estimated for $4^{\text {th }}-7^{\text {th }}$ graders Rivkin, Hanushek and Kain (2005, pp. 444-445) find that novice teachers were associated with math achievement gains of .103 standard deviations below those for teachers with six or more years of experience; for reading the novice deficit was .045 standard deviations. Rockoff (2004) finds the difference in reading scores between teachers with zero and ten years to be about .17. Our findings for zero versus 6-12 years of .08 5 and .064 for math and reading, respectively, are in this general range.

32 These results may appear to conflict Goldhaber and Anthony (2004), which is generally cited as a study finding significant p ositive effects of $\mathrm{N}$ ational Bo ard Certification. A close re ading of that article, however, reveals that no direct conflict exists. The Goldhaber and Anthony study finds that teachers who are destined to become National Board Certified in the future are most effective, and find no significant evidence that teachers who became certified in the past - the only group flagged in our analysis - are more or less effective than teachers who never applied for certification. Goldhaber and Anthon y also focus on older North Carolina data, from the late $1990 \mathrm{~s}$.
} 
effect of a master's degree on student achievement. The coefficients suggest that, all else constant, teachers with master's degrees are less effective than those without. ${ }^{33}$

In contrast to the teacher qualification variables, the coefficients of the teacher race variables in Table 6 continue to exhibit substantial variation across the specifications with and without controls for lagged student achievement. Because fixed effects for schools are included, the difference in coefficients can only be attributable to nonrandom assignment of teachers across classrooms within schools. In particular, it appears that black teachers tend to teach the lower performing math students within schools. Evidence for that conclusion emerges from that fact that once prior year performance is included in the equations, the coefficient for black teachers is closer to zero and not statistically significant.

Analogously, the fact that the inclusion of the lagged achievement score eliminates the statistically significant positive effect of class size that appears in columns 1 and 2 suggests that, consistent with Lazear's (2001) theoretical prediction, low performing students may be disproportionately placed in smaller classes within schools. The absence of class size effects in columns 3 and 4 does not mean that class size is irrelevant for student achievement. Instead it simply means that once we use school fixed effects to focus on differences within a school, we do not observe sufficient variation in class sizes to estimate an effect. This methodology is thus far better suited to measuring the effects of teachers, which do indeed vary quite significantly

\footnotetext{
33 In analysis not shown here, we find that the more experienced teachers have a far higher probability of having a master's degree than do the younger teachers. Further analysis of the characteristics of teach ers who get a master's deg ree would be desirab le. One interp retation of these results is that the financial incentives to get a master's degree that are embedded in the single salary schedule represented wasted money except insofar as they keep some teachers in the profession so that students $\mathrm{c}$ an benefit from their experience.
} 
within schools, than to measuring class size effects. ${ }^{34}$

Although we have a good bit of confidence in the estimated effects of teacher credentials that emerge from Table 6, these equations still might not fully address the bias that arises from within-school sorting. To address that source of bias, we restrict the sample to the schools in which students were assigned to classrooms in a balanced manner, namely the schools that failed none of the six $\chi^{2}$ tests for random assignment of students. While it is still possible for there to be some form of nonrandom selection into classrooms in these schools, any such selection would have to be along a dimension uncorrelated with any of the six characteristics used in our tests. ${ }^{35}$ If nothing else, the probability of selection on unobservables should be significantly lower in schools that do not also feature selection on unobservables.

Tables $1 \mathrm{a}$ and $1 \mathrm{~b}$ compare summary statistics for the overall sample and this evenly balanced school subsample, which includes roughly 40 percent of the full set of students. In general, the characteristics of teachers and students in the balanced school subsample are quite similar to those in the full sample. With respect to the characteristics of teachers, only the racial characteristics differ between the two samples, with the share of white teachers in the balanced school subsample being about 2 percentage points higher than the share in the full sample (Table 1a).

With respect to the two sets of students, a larger number of statistically significant

\footnotetext{
${ }^{34}$ By way of comparison, we estimated a school fixed effects model comparable to those in Table 6 using gains in achievement rather than the lagged dependent form. Except for differences in the first experience term (a larger effect for math and a smaller one for reading) and a large and significant positive effect for other race teachers, the estimated effects in the achievement gain model we re generally close to those in the lagged achievement model.

${ }^{35}$ Selection along most of the student-level characteristics used in our chi-squared tests is not an issue in many of our earlier estimates, since we control for most of those char acteristics directly. Rather, our g oal here is to identify schools that are less likely to select on unobservables ac ross classrooms.
} 
differences emerge, as shown in Table 1b. The students in the balanced school subsample are on average somewhat more advantaged, in the sense of being more white and have higher prior year test scores and parents with more education than those in the full sample. Still, the differences between the two samples are generally quite small in magnitude.

Table 7 shows the results of regression specifications identical to those in Table 6, including school fixed effects and student-level covariates, estimated on the balanced school subsample. Although the smaller sample generates somewhat larger standard errors and hence coefficients that are somewhat less precisely estimated, the patterns and estimated coefficients are quite similar to those obtained with the full sample. These findings provide added support for our previous conclusions about the effects of teacher credentials. The factors associated with higher student test scores in the full sample, namely teacher experience and teacher licensure test scores, continue to be significant predictors of achievement, with estimated magnitudes that are similar across the two samples. As with the full sample, the difference in test scores between students with novice teachers and those highly experienced teachers is roughly one-tenth of a standard deviation, with a large portion of these returns to experience occurring within the first few years of teaching. These experience effects are in the range of those found in other studies employing similar data, but smaller than the largest estimates. ${ }^{36}$ In addition, a one-standard deviation increase in a teacher's licensure test score now predicts a 0.012 standard deviation in student achievement in math.

In both Tables 6 and 7, coefficients exhibit a tendency to be higher when controls for lagged test scores are introduced as explanatory variables. In Table 7, the higher coefficients are

\footnotetext{
${ }^{36}$ See footnote 31 , above, for a discussion of estimates found in existing literature.
} 
somewhat troubling as they suggests that lagged test scores are correlated with teacher

characteristics even in schools that appear to be evenly balanced. Note, however, that the fact

that the coefficients are larger rules out the possibility of positive matching in evenly balanced

schools. Instead they suggest that teachers with better credentials in these schoools are being

assigned to less able students. If anything, then, the coefficients we report here are biased

towards zero - the opposite of the typical concern in studies of this nature. ${ }^{37}$

\section{Differential effects by type of student}

How teachers are distributed among schools and across classrooms within schools

relative to students clearly affects the distribution of student achievement. One final question is

whether it also affects the average level of achievement. The answer to this question hinges on

the existence of nonlinearities in the relationship between teacher characteristics and student

achievement. $^{38}$ To this point, our regression estimates have maintained the assumption that the

\footnotetext{
${ }^{37}$ To provide further evidence along these lines, we estimated models analogous to those in Table 7 for the set of schools that failed one or mo re tests for rand om assignm ent - that is, the set of schools excluded from Table 7 . These estimates are shown in Appendix Table A2. Comparing specifications with and without lagged achievement test scores reveals substantial evidence of bias associated with positive matching in this sample. The majority of teacher experience coefficients, for example, decline upon introduction of the lagged dependent variable.

We also estimated identical specifications using the set of schools where we uniformly failed to reject the null hypothesis of random assignment using the $20 \%$ significance level. Whereas the original $10 \%$ criterion produced a sample about $40 \%$ as large as the full sample, the $20 \%$ criterion yielded one slightly smaller than one fourth the original size. Results, shown in Appendix Table A3, show the same pattern of increasing upon introduction of lagged achievement controls shown in Table 7. The typical coefficient increase is smaller, however, suggesting that further increases in stringency would produce more com plete convergence of coefficients across specifications.

Finally, we note that coefficient magnitudes on teacher experience are similar across all specifications, lending greater confiden ce to the conclusion that any bias remaining in estimated specifications must be small.

${ }^{38}$ The answer to this question is also sensitive to the measurement of student achievement scores. Indeed, by testing for nonlinear effects on achievement we are assuming that we have identified a valid measure of achievement and are measuring it linearly. Nonlinear but monotonic transformations of our achievement test scores may be equally valid measures of achievement but may also yield very different conclusions regarding the existence of nonlinear effects. We proceed with this exercise under the presumption that the scale of our achievement measure is an important one for policy purposes - it is used by the State of North Carolina for the purpose of gauging
} 
effects of teacher qualifications do not vary systematically across types of students. Table 8 summarizes the results of regression specifications that relax this assumption by interacting the full set of teacher characteristics with particular student characteristics, including subsidized lunch receipt, parent education, and prior year achievement. ${ }^{39}$ The regressions are estimated on the sample of North Carolina elementary schools with evenly balanced classroom assignment patterns, using covariates identical to those employed in Table 7. The student characteristics are all defined as $0-1$ variables in which 1 denotes greater advantage or ability. The table reports coefficients and standard errors only for the interaction terms. ${ }^{40}$

The first column in Table 8 reveals evidence that math score returns to teacher experience are significantly larger for students not receiving subsidized lunches - that is, for the more affluent students. All six interaction terms related to teacher experience are positive. The two largest interaction terms, identifying the differential impact of teachers with at least 20 years' experience on students not receiving subsidized lunch, are statistically significant at the 10 and 5 perc ent level, respectively. ${ }^{41}$

progress in schools, and applying positive and negative sanctions to schools and their staff (Clotfelter, Ladd, Vigdor and Aliaga Diaz 2004).

39 In addition to these specifications, we estima ted models interacting stud ent race (no nwhite vs. white) with teacher characteristics. None of the interaction coefficients in these models was statistically significant. In the current study we do not examine the related question of whether students learn at higher rates when matched to a teacher of the same race or gender, an issue that has been examined by Dee (2005).

${ }^{40}$ Since Tables 7 and 8 both use the evenly balanced school subsample, comparison of the interaction terms in Table 8 with the corresponding main effects in Table 7 provides some insight as to the impact of teacher characteristics on the omitted group. For example, the two significant positive coefficients on teacher experience/non-subsidized lunch student in Table 8 are smaller than the corresponding main effects in Table 7 , indicating that the net impact of teacher experience on subsidized lunch students is still positive. Complete results of Table 8 are given in Appendix Table A 4.

${ }^{41}$ This table shows several significant coefficients associated with teachers from unranked colleges. As Table 1 a shows, rou ghly 1 percent of evenly ba lanced school subsam ple teachers fall into this category. Thus, this result quite likely reflects the impact of a very small number of influential observations. 
The second column, which replaces math with reading test scores as a dependent variable but otherwise replicates the first specification, shows no statistically significant interaction terms. This general pattern of significant interaction terms for math but not reading is replicated in the third and fourth columns, where we interact teacher characteristics with a dichotomous variable measuring parental education. More experienced teachers have a significantly more positive impact on the math test scores of students with more educated parents: all six interaction terms are positive, and three are significant at the 10 percent level or above. Children of highly educated parents also tend to have relatively higher math test scores when assigned to teachers who are neither black nor "other race," and who attended unranked colleges.

The final set of specifications interacts a dichotomous measure of prior achievement, based on students' $4^{\text {th }}$ grade test scores, with teacher characteristics. Although all six experience interactions are once again positive in the math specification, none is statistically significant. ${ }^{42}$

To the extent that these results indicate that teachers with stronger credentials are more effective in raising the achievement of the more advantaged students, they have two important implications. First, reallocating teachers to students in a manner that offsets the pattern of positive matching described in Section 4 above would have the likely effect of reducing mean achievement scores, at least for math and as measured on the scale used in North Carolina. However, the normative implications of this finding are unclear, for at least three reasons: we do not know how units of test scores correspond to actual skill accumulation at various points along the skill distribution; we do not know how fifth grade achievement affects lifetime skill

\footnotetext{
${ }^{42}$ Among the other results, it appears that Hispanic teachers have a comparative advantage in educating lower-performing studen ts. Since the evenly balanced school sub sample contains only a han dful of Hispanic teachers (see Table 1a), these results should be interpreted with extreme caution.
} 
accumulation; and we lack the broader measure of social welfare that would allow us to value skill enhancements. Thus any compelling welfare assessment is obviously well beyond the scope of this paper.

The second implication follows from the first: particularly in a regime that attaches incentives to the mean level of achievement within a school, school administrators may well consider positive matching to be consistent with their own objectives. Thus, the fact that we observe positive matching in equilibrium can be attributed to four forces: the desire of teachers to find more amenable working conditions, the desire of parents to maximize the quality of their children's education, the desire of administrators to please potentially vocal parents, and the desire of administrators to maximize mean achievement. This confluence of objectives may explain why the alternative pattern of negative matching, which would be expected in a regime that supported a progressive distribution of teacher and other resources among students, is not the empirical norm. ${ }^{43}$

\section{Conclusions}

The tendencies for teachers to seek out more congenial working environments and for parents to seek out desirable schools and teachers for their children are common features of public schools as we know them. Together, they usually produce a "positive matching" of students to teachers, in which affluent or high-achieving students end up in classrooms taught by

\footnotetext{
${ }^{43}$ It is worth noting that some school acco untability programs, including for examp le the federal No Child Left Behind Act, with its attention to the academic progress of subgroups within each school, could conceivably provide a counterweight by inducing administrators to pay closer attention to the achievement of less advantaged children.
} 
better-credentialed teachers. This positive matching has the effect of confounding efforts to estimate the relationship between teacher characteristics and student achievement. To our knowledge, no previous studies have identified and measured both of these sources of positive matching. Our results indicate that the positive correlations between the strength of teacher qualifications and student achievement observed in cross-sectional data are driven largely by sorting of teachers and students across schools and, to a lesser extent, within schools.

This paper illustrates, however, how detailed administrative data can be used to help disentangle omitted variable bias from true causal effects. Such data allow one to control for a rich set of covariates including school fixed effects, and to restrict the analysis to schools that feature a relatively balanced distribution of student observable characteristics across classrooms. Results suggest that the within-school matching is relatively minor in North Carolina, implying that specifications with school fixed effects ameliorate most concerns regarding selection bias.

We also find that the only teacher qualifications that consistently predict improved student performance are experience and licensure test scores. For the typical student, the benefit from having a highly experienced teacher is approximately one-tenth of a standard deviation on reading and math test scores. and roughly half of this return occurs for the first one or two years of teaching experience. ${ }^{44}$ With respect to teacher licensure scores, a one-standard-deviation increase in scores increases predicted student achievement in math by 1 to 2 percent of a standard deviation. These results suggest that achievement-maximizing school administrators operating in a competitive teacher labor market would clearly reward experience, as is the current norm.

\footnotetext{
44 It is unclear whether this return to early teacher experience reflects true gains in teacher quality or nonrandom attrition by low-quality teachers. See Rockoff (2004) for a discussion of this topic.
} 
Rewarding other characteristics, such as advanced degrees and National Board Certification, would be productive only if such rewards create indirect impacts, such as by inducing teachers to remain in the profession.

Using our subsample of evenly balanced schools, we find suggestive evidence that returns to teacher experience in the form of higher student test scores are consistently larger in math, although not in reading, for the more socioeconomically advantaged and more able students. This pattern supports the view that positive teacher-student matching increases the average level of student achievement in math and may help explain why school administrators have not been more vigorous in counteracting the positive matching that results from sorting.

It is worth reiterating that this conclusion about the trade-offs in the allocation of teachers to students with differing characteristics says nothing about the social valuation of those tradeoffs. Though it appears that efforts to offset the positive matching of teachers and students would reduce overall mean achievement in math as measured by test scores, the implications for social policy depend on at least two additional factors. First, the existence of complementarities in skill formation over a student's school career could militate in the direction of more investment for disadvantaged students, as suggested by Cunha, Heckman, Lochner and Masterov (2005). Second, because the ultimate outcomes of social interest are not test scores but rather a broader set of life chances it may well be appropriate to attach greater weight to achievement gains at the low end of the distribution. Thus, any social valuation of the trade-offs involved with positive matching require further debate and discussion by social scientists and policy makers. 


\section{References}

Aaronson, D., L. Barrow and W. Sander. (2003) “Teachers and Student Achievement in the Chicago Public High Schools.” Federal Reserve Bank of Chicago manuscript.

Altonji, J.G., T.E. Elder and C.R. Taber (2002) "Selection on Observed and Unobserved Variables: Assessing the Effectiveness of Catholic Schools.” Northwestern University manuscript.

Ballou, D., W. Sanders and P. Wright (2004) "Controlling for Student Background in ValueAdded Assessment of Teachers," Journal of Educational and Behavioral Statistics 29 (Spring), 37-66.

Becker, H.S. (1952) "The Career of the Chicago Public Schoolteacher," American Journal of Sociology v.57 pp.470-477.

Betts, J.R. (1996) "Is There a Link between School Inputs and Earnings? Fresh Scrutiny of an Old Literature." In Gary Burtless, ed., Does Money Matter: The Effect of School Resources on Student Achievement and Adult Success. Washington, D.C.: Brookings Institution Press, pp. 141191.

Betts, J.R., A. Zau and L. Rice (2003) Determinants of Student Achievement: Evidence from San Diego. San Francisco: Public Policy Institute of California.

Boardman, E.E. and R.J. Murnane. (1979) "Using Panel Data to Improve Estimates of the Determinants of Educational Achievement." Sociology of Education v.52 pp.113-121.

Bogart, W. T., and B. A. Cromwell. (2000) "How Much is a Neighborhood School Worth?" Journal of Urban Economics 47: 280-305.

Card , D. and A.B. Krueger. (1992) "Does School Quality Matter? Returns to Education and the Characteristics of Public Schools in the United States." Journal of Political Economy v.100 pp.140 .

Clotfelter, C.T., H.F. Ladd, and J.L. Vigdor. (2003) "Segregation and Resegregation in North Carolina's Public School Classrooms," North Carolina Law Review v.81 pp.1463-1511.

Clotfelter, C.T., H.F. Ladd, and J.L. Vigdor (2004) "Who Teaches Whom? Race and the Distribution of Novice Teachers." Forthcoming, Economics of Education Review.

Clotfeter, C.T., H.F. Ladd, J.L. Vigdor and R.A. Aliaga Diaz (2004) "Do School Accountability Systems Make It More Difficult for Low Performing Schools to Attract and Retain High Quality Teachers?" Journal of Policy Analysis and Management v.23 pp.251-271. 
Coleman, J.S. et al. (1966) Equality of Educational Opportunity. Washington: Office of Education, US Department of Health, Education and Welfare.

Cunha, F., J.J. Heckman, L. Lochner, and D.V. Masterov (2005) "Interpreting the Evidence on Life Cycle Skill Formation,” NBER Working Paper 11331, May 2005.

Dee, T.S., “A Teacher Like Me: Does Race, Ethnicity, or Gender Matter?” American Economic Review 95 (May 2005), 158-165.

Freeman, C., B. Scafidi, and D. Sjoquist. (2002) "Racial Segregation in Georgia Public Schools, 1994-2001: Trends, Causes, and Impact on Teacher Quality," Fiscal Research Program Report 77, Georgia State University.

Goldhaber, D. and E. Anthony (2004) “Can Teacher Quality be Effectively Assessed?” Urban Institute Working Paper.

Goldhaber, D.D. and D.Brewer (2000) "Does Teacher Certification Matter? High School Teacher Certification Status and Student Achievement." Educational Evaluation and Policy Analysis v.22 pp.129-45.

Hanushek, E.A. (1986) "The Economics of Schooling: Production and Efficiency in Public Schools," Journal of Economic Literature v.24 pp.1141-1177.

Hanushek, E.A. (1997). Assessing the Effects of School Resources on Student Performance: An Update. Educational Evaluation and Policy Analysis 19(2): 141-164.

Hanushek, E.A. (2002) “Publicly Provided Education,” NBER Working Paper 8799, February.

Hanushek, E. A., J. F. Kain, D. M. O’Brien and S.G. Rivkin (2005) “The Market for Teacher Quality," unpublished paper, Stanford University, January.

Hausman, J. (1978) “Specification Tests in Econometrics.” Econometrica v.46 pp.1251-1271.

Hollingshead, August B. (1949) Elmtown's Youth: The Impact of Social Classes on Adolescents New York: John Wiley and Sons, Inc.

Hui, T. Keung. (2003). "It's teacher shopping season: Principals gently wield veto power over parents who request popular teachers." News and Observer, July 15, p. 1. (newsobserver.com/front/story/2694508p-2498214c.html).

Krueger, A.B. (1999) "Experimental Estimates of Education Production Functions.” Quarterly Journal of Economics v.114 pp.497-532. 
LaLonde, R.J. (1986) "Evaluating the Econometric Evaluations of Training Programs with Experimental Data," American Economic Review 76 (September), 604-620.

Lankford, H., S. Loeb, and J. Wyckoff. (2002) "Teacher Sorting and the Plight of Urban Schools," Educational Evaluation and Policy Analysis v.24 pp.37-62.

Lalonde, R., "Evaluating the Econometric Evaluations of Training Programs with experimental Data," American Economic Review 76, 604-620

Lareau, A. (1987) "Social Class Differences in Family-School Relationships: The Importance of Cultural Capital," Sociology of Education v.60 pp.73-85.

Lareau, A. (2000) Home Advantage. (Lanham: Rowman and Littlefield Publishers).

Mont, Daniel and Daniel I. Rees. (1996) “The Influence of Classroom Characteristics on High School Teacher Turnover," Economic Inquiry 34 (January), 152-167.

Morgan, P.R. and J.M. McPartland. (1981) "The Extent of Classroom Segregation within Desegregated Schools.” Unpublished manuscript, Johns Hopkins University, Center for Social Organization of Schools. August.

Mickelson, R.A., (2001) "Subverting Swann: First- and Second-Generation Segregation in the Charlotte-Mecklenburg Schools," American Education Research Journal, v.38 pp.215-252.

Mont, D. and D.I. Rees (1996) “The Influence of Classroom Characteristics on High School Teacher Turnover,” Economic Inquiry v.34 pp.152-167.

Murnane, R. and R. Olsen. (1989) "Will There be Enough Teachers?" American Economic Review v.79 pp.242-246.

Nye, B., S. Konstantopoulos, and L.V. Hedges (2004) "How Large Are Teacher Effects?" Educational Evaluation and Policy Analysis v.26 n.3

Oakes, J. (1995) “Ability Grouping, Tracking and Within-School Segregation in New Castle County Schools," Report to the U.S. district Court for the District of Delaware in the case of Coalition to Save our Children v. State Board of Education, et al. December 9, 1994 (corrected January 1, 1995).

Public Education Association (New York City). (1955) The Status of the Public School Education of Negro and Puerto Rican Children in New York City, Board of Education Commission on Integration, October.

Rivkin, S.G., E.A. Hanushek, and J.F. Kain (2005) “Teachers, Schools and Academic 
Achievement." Econometrica v.79 pp.418-458.

Rockoff, J.E. (2004) “The Impact of Individual Teachers on Student Achievement: Evidence from Panel Data," American Economic Review Papers and Proceedings (May 2004), 247-252.

Reed, D. and K. Rueben, 2002 "Teacher Turnover in California," unpublished paper, Public Policy Institute of California, October 31, 2002.

Sieber, R. T. (1982) "The Politics of Middle Class Success in an Inner-City Public School," Boston University Journal of Education v.30 pp.30-47.

Summers, A.A. and B.L. Wolfe (1977) "Do Schools Make A Difference?" American Economic Review v.67 pp.639-652.

Tiebout, C. M. (1956) “A Pure Theory of Local Expenditures,” Journal of Political Economy 64 (October), 416-424.

Todd, P.E. and K.I. Wolpin (2003) "On the Specification and Estimation of the Production Function for Cognitive Achievement," Economic Journal 113 (February), F3-F33.

$\mathrm{g}: \backslash$ teachq $\backslash$ papers $\backslash$ tsjhr-ctcrev 
Table 1a: Summary Statistics for $5^{\text {th }}$ grade teachers in North Carolina

\begin{tabular}{|c|c|c|}
\hline & $\begin{array}{l}\text { Full sample } \\
(N=3,223)\end{array}$ & $\begin{array}{l}\text { Evenly balanced school } \\
\text { subsample }(N=1,287)\end{array}$ \\
\hline Percent female & 90.32 & 91.30 \\
\hline Percent white & 84.64 & $86.48^{* *}$ \\
\hline Percent black & 14.24 & $12.43^{* *}$ \\
\hline Percent Hispanic & 0.22 & 0.31 \\
\hline \multicolumn{3}{|l|}{ Percent with: } \\
\hline 0 years experience & 7.38 & 7.46 \\
\hline $1-2$ years experience & 13.34 & 13.52 \\
\hline 3-5 years experience & 15.02 & 14.30 \\
\hline 6-12 years experience & 21.84 & 22.84 \\
\hline 13-20 years experience & 16.29 & 16.47 \\
\hline 20-27 years experience & 17.00 & 15.77 \\
\hline More than 27 years experience & 9.12 & 9.63 \\
\hline \multicolumn{3}{|l|}{ Percent with licensure test scores: } \\
\hline Within 1 std. dev. of mean & 72.54 & 73.82 \\
\hline 1 std. dev. or more above mean & 9.62 & 9.32 \\
\hline \multicolumn{3}{|l|}{ Percent graduating from college: } \\
\hline Ranked as very competitive & 9.22 & 9.17 \\
\hline Ranked as competitive & 53.74 & 55.17 \\
\hline Ranked as less competitive & 36.18 & 34.65 \\
\hline Not ranked by Barron's & 0.87 & 1.01 \\
\hline Percent National Board Certified & 3.35 & 3.26 \\
\hline Percent with advanced degree & 23.67 & 23.85 \\
\hline
\end{tabular}


Table 1 b. Summary Statistics for $5^{\text {th }}$ grade students in North Carolina $(N=60,791)$

\begin{tabular}{|c|c|c|}
\hline & $\begin{array}{l}\text { Full sample } \\
(N=60,791) \\
\end{array}$ & $\begin{array}{l}\text { Evenly ba lanced sch ool subsam ple } \\
\qquad(N=24,824)\end{array}$ \\
\hline Percent fem ale & 49.88 & 49.67 \\
\hline Percent white & 62.51 & $65.46^{* *}$ \\
\hline Percent black & 29.93 & $27.25^{* *}$ \\
\hline Percent $\mathrm{H}$ ispanic & 3.19 & 3.26 \\
\hline Percent free/reduced price lunch & 41.91 & $40.19^{* *}$ \\
\hline Percent labeled as gifted & 16.56 & 16.83 \\
\hline Percent labeled as handicapped & 10.66 & 10.90 \\
\hline Percent limited English proficient & 1.22 & $1.33^{* *}$ \\
\hline \multicolumn{3}{|l|}{ Percent with $4^{\text {th }}$ grade test score } \\
\hline 1 std. dev. or more below mean & 16.07 & $15.14^{* *}$ \\
\hline Within 1 std. dev. of mean & 67.10 & 66.93 \\
\hline 1 std. dev. or more above mean & 16.83 & $17.93^{* *}$ \\
\hline Percent who have repeated a grade & 1.08 & 1.12 \\
\hline \multicolumn{3}{|l|}{ Percent with parental education: } \\
\hline No high school diploma & 10.24 & $11.15^{* *}$ \\
\hline High school diploma o nly & 51.04 & $48.45^{* *}$ \\
\hline Some post secondary & 13.75 & $14.12^{* *}$ \\
\hline College graduate & 25.00 & $26.28^{* *}$ \\
\hline \multicolumn{3}{|l|}{ Percent reporting homework time: } \\
\hline None & 1.57 & 1.53 \\
\hline Less than 1 hour per week & 25.72 & $24.98^{* *}$ \\
\hline 1-3 hours per week & 39.65 & $40.15^{* *}$ \\
\hline 3-5 hours per week & 16.85 & 17.08 \\
\hline 5-10 hours per week & 13.11 & 13.07 \\
\hline More than 10 hours per week & 3.10 & 3.19 \\
\hline \multicolumn{3}{|l|}{ Percent re porting ho me PC use: } \\
\hline Almost every day & 5.03 & 5.05 \\
\hline Once or twice a week & 11.67 & 11.56 \\
\hline Once or twice a month & 17.27 & 17.18 \\
\hline Hardly ever & 29.35 & 29.64 \\
\hline Never & 18.70 & 18.80 \\
\hline No computer at home & 17.98 & 17.77 \\
\hline \multicolumn{3}{|l|}{ Percent reporting reading: } \\
\hline No free time spent reading & 6.20 & 6.05 \\
\hline 30 minutes per day & 45.87 & $44.95^{* *}$ \\
\hline 1 hour per day & 25.17 & $26.17^{* *}$ \\
\hline 1-2 hours per day & 15.24 & 15.32 \\
\hline More than 2 hours per day & 7.52 & 7.50 \\
\hline \multicolumn{3}{|l|}{ Percent reporting $\mathrm{TV}$ use } \\
\hline None & 4.84 & 4.89 \\
\hline Less than 1 hour per day & 28.48 & $29.23^{* *}$ \\
\hline 2 hours per day & 25.84 & 25.98 \\
\hline 3 hours per day & 18.64 & 18.78 \\
\hline 4-5 hours per day & 12.94 & $12.62^{*}$ \\
\hline 6 hours or more per day & 9.26 & $8.49^{* *}$ \\
\hline
\end{tabular}


Table 2. Evidence of across-school sorting: Characteristics of students taught by the typical teacher having specified qualification, North Carolina schools offering $5^{\text {th }}$ grade

\begin{tabular}{|c|c|c|c|c|}
\hline Teacher qualification & $\begin{array}{l}\text { Percent } \\
\text { white }\end{array}$ & $\begin{array}{l}\text { Percent not } \\
\text { receiving } \\
\text { subsidized } \\
\text { lunch }\end{array}$ & $\begin{array}{l}\text { Percent with } \\
\text { parents who are } \\
\text { college graduate } \\
\text { parents }\end{array}$ & $\begin{array}{c}\text { Mean prior } \\
\text { year test } \\
\text { score }(Z)\end{array}$ \\
\hline \multicolumn{5}{|l|}{ Teacher experience: } \\
\hline 2 to 5 years & 58.2 & 54.4 & 23.8 & -0.072 \\
\hline 6 or more years & 62.8 & 54.5 & 23.5 & 0.000 \\
\hline \multicolumn{5}{|l|}{ Barron's College Rank: } \\
\hline Competitive & 64.4 & 57.1 & 24.4 & 0.118 \\
\hline Very competitive & 59.3 & 58.2 & 30.4 & 0.126 \\
\hline Not Ranked & 58.8 & 53.5 & 24.9 & -0.047 \\
\hline \multicolumn{5}{|l|}{ Licensure test score: } \\
\hline$-1<Z$-score $<1$ & 62.9 & 56.0 & 24.3 & 0.054 \\
\hline$Z$-score $>1$ & 66.2 & 58.4 & 26.8 & 0.158 \\
\hline $\begin{array}{l}\text { Nat'l Board Certificat } \\
\text { No }\end{array}$ & \multicolumn{3}{|c|}{ Nat'1 Board Certification } & 0.000 \\
\hline Yes & 65.0 & 57.6 & 23.8 & -0.002 \\
\hline \multicolumn{5}{|l|}{ Advanced Degree } \\
\hline No & 60.0 & 53.5 & 22.9 & -0.043 \\
\hline Yes & 64.9 & 57.8 & 25.2 & 13.8 \\
\hline Overall mean & 61.1 & 54.5 & 23.5 & 0.000 \\
\hline
\end{tabular}

Note: For teachers with a given qualification, table entries are averages of school-wide figures computed over those schools with at least one such teacher. Using $F$-tests, the hypothesis that student characteristics are equal across teacher qualification categories is rejected in all but the following cases: teacher experience and percent of students with parents who are college graduates; teacher National Board Certification and all four student characteristics. 
Table 3: Evidence of within-school sorting: classroom characteristics for teachers with varying qualifications, relative to school, North Carolina schools with more than one $5^{\text {th }}$ grade class

\begin{tabular}{|c|c|c|c|c|}
\hline Teacher characteristic & $\begin{array}{l}\text { Percent } \\
\text { white }\end{array}$ & $\begin{array}{l}\text { Percent not } \\
\text { receiving } \\
\text { subsidized } \\
\text { lunch } \\
\end{array}$ & $\begin{array}{l}\text { Percent with } \\
\text { parents who are } \\
\text { college } \\
\text { graduates }\end{array}$ & $\begin{array}{c}\text { Mean prior } \\
\text { year test } \\
\text { score }(Z)\end{array}$ \\
\hline $\begin{array}{l}\text { Teacher experience: } \\
0 \text { to } 1 \text { year }\end{array}$ & 0.99 & 0.97 & $0.94 *$ & -0.050 \\
\hline 2 to 5 years & 1.01 & 1.00 & 1.00 & 0.004 \\
\hline 6 or more years & 1.00 & 1.00 & 1.00 & 0.009 \\
\hline $\begin{array}{l}\text { Barron's College Rank: } \\
\text { Less competitive }\end{array}$ & 1.00 & 1.00 & 0.98 & $-0.052^{*}$ \\
\hline Competitive & 0.99 & 0.99 & 1.00 & 0.017 \\
\hline Very competitive & 1.04 & 1.00 & 1.07 & $0.052^{*}$ \\
\hline Not Ranked & 0.97 & 0.87 & 1.08 & -0.184 \\
\hline $\begin{array}{l}\text { Licensure test score: } \\
\quad Z \text {-score }<-1\end{array}$ & $0.98^{* * *}$ & 0.98 & $0.94^{*}$ & $-0.133^{* * *}$ \\
\hline$-1<Z$-score $<1$ & 1.01 & 1.01 & 1.00 & 0.023 \\
\hline$Z$-score $>1$ & 1.01 & 1.00 & 1.08 & $0.075^{* *}$ \\
\hline $\begin{array}{l}\text { Nat'l Board Certificatio } \\
\quad \text { No }\end{array}$ & 1.00 & 1.00 & 0.99 & -0.006 \\
\hline Yes & 1.06 & $1.11^{*}$ & $1.23^{* *}$ & $0.182^{* *}$ \\
\hline $\begin{array}{l}\text { Advanced Degree } \\
\text { No }\end{array}$ & 1.00 & 1.00 & 1.00 & 0.004 \\
\hline Yes & 0.99 & 0.98 & 1.00 & -0.011 \\
\hline
\end{tabular}

Note: For teachers with a given qualification, table entries in the first three columns are ratios of classroom characteristics to school-wide averages. Table entries in the last column are mean differences between classroom and school-average test scores.

${ }^{* * *}$ denotes a ratio or mean difference significantly different from one at the $1 \%$ level; ${ }^{* *}$ the $5 \%$ level; ${ }^{*}$ the $10 \%$ level. 
Table 4: Summary of Chi-squared tests of random assignment of students across $5^{\text {th }}$ classrooms within elementary schools

\begin{tabular}{lcc}
\hline Number of tests failed & $\begin{array}{c}\text { Number of } \\
\text { schools }\end{array}$ & Percent of schools \\
\hline 0 of 6 & 521 & 44.9 \\
1 of 6 & 326 & 28.1 \\
2 of 6 & 163 & 14.1 \\
3 of 6 & 75 & 6.5 \\
4 of 6 & 41 & 3.5 \\
5 of 6 & 14 & 1.2 \\
6 of 6 & 0 & 0.0 \\
& 1,160 & 100.0 \\
Total & & \\
\hline $\begin{array}{l}\text { Note: This table reports the results of Chi-squared tests of the null hypothesis that students are } \\
\text { randomly distributed across classrooms within schools along six different observable student } \\
\text { characteristics: race, gender, subsidized lunch receipt, parental education, previous year test }\end{array}$ \\
score, and previous year school attendance. The tests are based on data on the composition of \\
classes for up to three grades in each school; significance is based on the 10 percent level. \\
See text for further details.
\end{tabular}


Table 5: Basic estimates of teacher qualification effects, with and without student controls

\begin{tabular}{|c|c|c|c|c|c|c|}
\hline \multirow{3}{*}{ Indepen dent Variable } & \multirow{2}{*}{\multicolumn{2}{|c|}{ No student covariates }} & \multicolumn{4}{|c|}{ Including student covariates } \\
\hline & & & \multicolumn{2}{|c|}{ Omitting lagged achievement } & \multicolumn{2}{|c|}{ Including lagged achievement } \\
\hline & Math & Reading & Math & Reading & Math & Reading \\
\hline Black teacher & $\begin{array}{c}-0.248^{* * *} \\
{[0.026]}\end{array}$ & $\begin{array}{c}-0.244^{* * *} \\
{[0.025]}\end{array}$ & $\begin{array}{l}0.061^{* * *} \\
{[0.017]}\end{array}$ & $\begin{array}{c}-0.059^{* * *} \\
{[0.015]}\end{array}$ & $\begin{array}{c}-0.019 \\
{[0.014]}\end{array}$ & $\begin{array}{c}-0.016 \\
{[0.011]}\end{array}$ \\
\hline Hispanic teacher & $\begin{array}{c}0.181 \\
{[0.141]}\end{array}$ & $\begin{array}{c}0.284^{*} \\
{[0.151]}\end{array}$ & $\begin{array}{c}0.069 \\
{[0.101]}\end{array}$ & $\begin{array}{c}0.062 \\
{[0.066]}\end{array}$ & $\begin{array}{c}-0.06 \\
{[0.070]}\end{array}$ & $\begin{array}{c}0.072 \\
{[0.046]}\end{array}$ \\
\hline Other race teacher & $\begin{array}{c}-0.243^{* * *} \\
{[0.081]}\end{array}$ & $\begin{array}{c}-0.294^{* * *} \\
{[0.080]}\end{array}$ & $\begin{array}{l}0.134^{* * *} \\
{[0.049]}\end{array}$ & $\begin{array}{c}-0.181^{* * *} \\
{[0.048]}\end{array}$ & $\begin{array}{c}-0.051 \\
{[0.043]}\end{array}$ & $\begin{array}{c}-0.097^{* *} \\
{[0.045]}\end{array}$ \\
\hline Male teacher & $\begin{array}{c}-0.057^{* *} \\
{[0.027]}\end{array}$ & $\begin{array}{c}-0.090^{* * *} \\
{[0.025]}\end{array}$ & $\begin{array}{c}0.007 \\
{[0.019]}\end{array}$ & $\begin{array}{l}-0.031^{* *} \\
{[0.016]}\end{array}$ & $\begin{array}{c}0.004 \\
{[0.014]}\end{array}$ & $\begin{array}{c}-0.034^{* * *} \\
{[0.012]}\end{array}$ \\
\hline \multicolumn{7}{|c|}{ Teacher exp erience (base $=0$ years) } \\
\hline 1-2 years experience & $\begin{array}{c}0.060^{*} \\
{[0.035]}\end{array}$ & $\begin{array}{c}0.046 \\
{[0.032]}\end{array}$ & $\begin{array}{c}0.029 \\
{[0.023]}\end{array}$ & $\begin{array}{c}0.017 \\
{[0.020]}\end{array}$ & $\begin{array}{l}0.058^{* * *} \\
{[0.019]}\end{array}$ & $\begin{array}{l}0.046^{* * *} \\
{[0.015]}\end{array}$ \\
\hline 3-5 years experience & $\begin{array}{l}0.108^{* * *} \\
{[0.035]}\end{array}$ & $\begin{array}{l}0.081^{* *} \\
{[0.032]}\end{array}$ & $\begin{array}{l}0.074^{* * *} \\
{[0.023]}\end{array}$ & $\begin{array}{l}0.049^{* *} \\
{[0.020]}\end{array}$ & $\begin{array}{l}0.082^{* * *} \\
{[0.018]}\end{array}$ & $\begin{array}{l}0.055^{* * *} \\
{[0.015]}\end{array}$ \\
\hline $6-12$ years experience & $\begin{array}{l}0.170^{* * *} \\
{[0.034]}\end{array}$ & $\begin{array}{l}0.142^{* * *} \\
{[0.030]}\end{array}$ & $\begin{array}{l}0.084^{* * *} \\
{[0.022]}\end{array}$ & $\begin{array}{l}0.064^{* * *} \\
{[0.019]}\end{array}$ & $\begin{array}{l}0.086^{* * *} \\
{[0.018]}\end{array}$ & $\begin{array}{l}0.067^{* * *} \\
{[0.014]}\end{array}$ \\
\hline $\begin{array}{l}13-20 \text { years } \\
\text { experience }\end{array}$ & $\begin{array}{l}0.181^{* * *} \\
{[0.035]}\end{array}$ & $\begin{array}{l}0.178^{* * *} \\
{[0.032]}\end{array}$ & $\begin{array}{l}0.085^{* * *} \\
{[0.023]}\end{array}$ & $\begin{array}{l}0.085^{* * *} \\
{[0.020]}\end{array}$ & $\begin{array}{l}0.077^{* * *} \\
{[0.018]}\end{array}$ & $\begin{array}{l}0.078^{* * *} \\
{[0.015]}\end{array}$ \\
\hline $\begin{array}{l}20-27 \text { years } \\
\text { experience }\end{array}$ & $\begin{array}{l}0.179^{* * *} \\
{[0.035]}\end{array}$ & $\begin{array}{l}0.172^{* * *} \\
{[0.032]}\end{array}$ & $\begin{array}{l}0.086^{* * *} \\
{[0.023]}\end{array}$ & $\begin{array}{l}0.086^{* * *} \\
{[0.020]}\end{array}$ & $\begin{array}{l}0.093^{* * *} \\
{[0.018]}\end{array}$ & $\begin{array}{l}0.091^{* * *} \\
{[0.015]}\end{array}$ \\
\hline$>27$ years experience & $\begin{array}{l}0.160^{* * *} \\
{[0.039]}\end{array}$ & $\begin{array}{l}0.147^{* * *} \\
{[0.035]}\end{array}$ & $\begin{array}{l}0.094^{* * *} \\
{[0.026]}\end{array}$ & $\begin{array}{l}0.081^{* * *} \\
{[0.023]}\end{array}$ & $\begin{array}{l}0.104^{* * *} \\
{[0.021]}\end{array}$ & $\begin{array}{l}0.092^{* * *} \\
{[0.017]}\end{array}$ \\
\hline \multicolumn{7}{|c|}{ Quality of teacher's college (base $=$ less competitive) } \\
\hline competitive college & $\begin{array}{l}0.083^{* * *} \\
{[0.018]}\end{array}$ & $\begin{array}{l}0.097^{* * *} \\
{[0.016]}\end{array}$ & $\begin{array}{c}0.01 \\
{[0.012]}\end{array}$ & $\begin{array}{l}0.026^{* * *} \\
{[0.010]}\end{array}$ & $\begin{array}{c}0.000 \\
{[0.009]}\end{array}$ & $\begin{array}{c}0.014^{*} \\
{[0.007]}\end{array}$ \\
\hline $\begin{array}{l}\text { very competitive } \\
\text { college }\end{array}$ & $\begin{array}{l}0.123^{* * *} \\
{[0.031]}\end{array}$ & $\begin{array}{l}0.111^{* * *} \\
{[0.029]}\end{array}$ & $\begin{array}{c}0.028 \\
{[0.019]}\end{array}$ & $\begin{array}{c}0.025 \\
{[0.017]}\end{array}$ & $\begin{array}{c}0.024 \\
{[0.015]}\end{array}$ & $\begin{array}{c}0.017 \\
{[0.013]}\end{array}$ \\
\hline unranked college & $\begin{array}{l}-0.018 \\
{[0.094]}\end{array}$ & $\begin{array}{c}0.019 \\
{[0.096]}\end{array}$ & $\begin{array}{l}-0.023 \\
{[0.053]}\end{array}$ & $\begin{array}{c}0.003 \\
{[0.048]}\end{array}$ & $\begin{array}{l}-0.032 \\
{[0.041]}\end{array}$ & $\begin{array}{l}-0.003 \\
{[0.043]}\end{array}$ \\
\hline $\begin{array}{l}\text { Teacher with } \\
\text { advanced degree }\end{array}$ & $\begin{array}{c}0.010 \\
{[0.020]}\end{array}$ & $\begin{array}{c}0.015 \\
{[0.018]}\end{array}$ & $\begin{array}{l}-0.028^{* *} \\
{[0.013]}\end{array}$ & $\begin{array}{l}-0.023^{* *} \\
{[0.011]}\end{array}$ & $\begin{array}{c}-0.028^{* * *} \\
{[0.010]}\end{array}$ & $\begin{array}{c}-0.023^{* * *} \\
{[0.008]}\end{array}$ \\
\hline $\begin{array}{l}\text { Teacher Nat'l Board } \\
\text { Certified }\end{array}$ & $\begin{array}{c}0.026 \\
{[0.047]}\end{array}$ & $\begin{array}{c}0.035 \\
{[0.041]}\end{array}$ & $\begin{array}{c}0.004 \\
{[0.031]}\end{array}$ & $\begin{array}{c}0.018 \\
{[0.022]}\end{array}$ & $\begin{array}{c}0.008 \\
{[0.024]}\end{array}$ & $\begin{array}{c}0.024 \\
{[0.016]}\end{array}$ \\
\hline $\begin{array}{l}\text { Teacher's licensure } \\
\text { test score }\end{array}$ & $\begin{array}{l}0.060^{* * *} \\
{[0.010]}\end{array}$ & $\begin{array}{l}0.048^{* * *} \\
{[0.009]}\end{array}$ & $\begin{array}{l}0.023^{* * *} \\
{[0.007]}\end{array}$ & $\begin{array}{l}0.015^{* * *} \\
{[0.006]}\end{array}$ & $\begin{array}{l}0.018^{* * *} \\
{[0.005]}\end{array}$ & $\begin{array}{l}0.011^{* *} \\
{[0.004]}\end{array}$ \\
\hline Class size & $\begin{array}{l}0.017^{* * *} \\
{[0.003]}\end{array}$ & $\begin{array}{l}0.018^{* * *} \\
{[0.002]}\end{array}$ & $\begin{array}{l}-0.001 \\
{[0.002]}\end{array}$ & $\begin{array}{c}0.001 \\
{[0.001]}\end{array}$ & $\begin{array}{l}-0.002 \\
{[0.001]}\end{array}$ & $\begin{array}{c}0 \\
{[0.001]}\end{array}$ \\
\hline Student covariates & No & No & Yes & Yes & Yes & Yes \\
\hline $\begin{array}{l}\text { Lagged student } \\
\text { achievem ent controls }\end{array}$ & No & No & No & No & Yes & Yes \\
\hline Observations & 68,421 & 68,071 & 61,509 & 61,242 & 60,656 & 60,502 \\
\hline $\mathrm{R}^{2}$ & 0.027 & 0.026 & 0.484 & 0.449 & 0.724 & 0.687 \\
\hline $\begin{array}{l}\text { Note: stand ard errors, } \\
\text { significance at the } 10 \% \\
\text { status. Extended set of } \\
\text { watching TV, parental } \\
\text { presented in Appendix }\end{array}$ & $\begin{array}{l}\text { uare brac } \\
\text { o and } 1 \% \\
\text { trols inclu } \\
\text { cation, an } \\
\text { e A1. }\end{array}$ & $\begin{array}{l}\text { ave been } \\
\text { ategorical } \\
\text { spent on }\end{array}$ & $\begin{array}{l}\text { ected for } \\
\text { ic control } \\
\text { isures of c } \\
\text { ework. C }\end{array}$ & $\begin{array}{l}\text { lassroom c } \\
\text { e gender, } r \\
\text { r use, time } \\
\text { ents on exte }\end{array}$ & $\begin{array}{l}\text { tering. } \\
\text { and free/re } \\
\text { ent free read } \\
\text { ed student c }\end{array}$ & $\begin{array}{l}\text { denote } \\
\text { price lunch } \\
\text { me spent } \\
\text { s are }\end{array}$ \\
\hline
\end{tabular}


Table 6. Effects of teach er qualifications, with school fixed effects, full sample

\begin{tabular}{|c|c|c|c|c|}
\hline \multirow[b]{2}{*}{ Indepen dent Variable } & \multicolumn{2}{|c|}{ Omitting lagged achievement } & \multicolumn{2}{|c|}{ Including lagged achievement } \\
\hline & Math & Reading & Math & Reading \\
\hline Black teacher & $\begin{array}{l}0.030^{* *} \\
{[0.014]}\end{array}$ & $\begin{array}{c}-0.020 \\
{[0.013]}\end{array}$ & $\begin{array}{c}-0.016 \\
{[0.011]}\end{array}$ & $\begin{array}{c}-0.007 \\
{[0.010]}\end{array}$ \\
\hline Hispanic teacher & $\begin{array}{c}0.129 \\
{[0.107]}\end{array}$ & $\begin{array}{l}0.165^{* * *} \\
{[0.046]}\end{array}$ & $\begin{array}{c}0.026 \\
{[0.069]}\end{array}$ & $\begin{array}{c}0.052 \\
{[0.045]}\end{array}$ \\
\hline Other race teacher & $\begin{array}{c}0.009 \\
{[0.044]}\end{array}$ & $\begin{array}{c}0.02 \\
{[0.050]}\end{array}$ & $\begin{array}{c}0.018 \\
{[0.034]}\end{array}$ & $\begin{array}{c}0.022 \\
{[0.030]}\end{array}$ \\
\hline Male teacher & $\begin{array}{c}0.019 \\
{[0.014]}\end{array}$ & $\begin{array}{l}-0.022^{*} \\
{[0.013]}\end{array}$ & $\begin{array}{c}0.016 \\
{[0.011]}\end{array}$ & $\begin{array}{c}-0.023^{* *} \\
{[0.009]}\end{array}$ \\
\hline \multicolumn{5}{|l|}{ Teacher exp erience (base $=0$ years $)$} \\
\hline 1-2 years experience & $\begin{array}{l}0.052^{* * *} \\
{[0.018]}\end{array}$ & $\begin{array}{l}0.035^{* *} \\
{[0.017]}\end{array}$ & $\begin{array}{l}0.051^{* * *} \\
{[0.014]}\end{array}$ & $\begin{array}{l}0.035^{* * *} \\
{[0.013]}\end{array}$ \\
\hline 3-5 years experience & $\begin{array}{l}0.077^{* * *} \\
{[0.018]}\end{array}$ & $\begin{array}{l}0.045^{* * *} \\
{[0.017]}\end{array}$ & $\begin{array}{l}0.078^{* * *} \\
{[0.014]}\end{array}$ & $\begin{array}{l}0.046^{* * *} \\
{[0.013]}\end{array}$ \\
\hline $6-12$ years experience & $\begin{array}{l}0.075^{* * *} \\
{[0.018]}\end{array}$ & $\begin{array}{l}0.047^{* * *} \\
{[0.017]}\end{array}$ & $\begin{array}{l}0.076^{* * *} \\
{[0.014]}\end{array}$ & $\begin{array}{l}0.051^{* * *} \\
{[0.013]}\end{array}$ \\
\hline 13-20 years experience & $\begin{array}{l}0.084^{* * *} \\
{[0.019]}\end{array}$ & $\begin{array}{l}0.059^{* * *} \\
{[0.018]}\end{array}$ & $\begin{array}{l}0.089^{* * *} \\
{[0.015]}\end{array}$ & $\begin{array}{l}0.065^{* * *} \\
{[0.014]}\end{array}$ \\
\hline 20-27 years experience & $\begin{array}{l}0.096^{* * *} \\
{[0.018]}\end{array}$ & $\begin{array}{l}0.077^{* * *} \\
{[0.017]}\end{array}$ & $\begin{array}{l}0.096^{* * *} \\
{[0.014]}\end{array}$ & $\begin{array}{l}0.079^{* * *} \\
{[0.013]}\end{array}$ \\
\hline$>27$ years experience & $\begin{array}{l}0.076^{* * *} \\
{[0.020]}\end{array}$ & $\begin{array}{l}0.051^{* * *} \\
{[0.019]}\end{array}$ & $\begin{array}{l}0.090^{* * *} \\
{[0.016]}\end{array}$ & $\begin{array}{l}0.067^{* * *} \\
{[0.014]}\end{array}$ \\
\hline \multicolumn{5}{|c|}{ Quality of teacher's college (base=less competitive) } \\
\hline competitive college & $\begin{array}{c}0.011 \\
{[0.010]}\end{array}$ & $\begin{array}{c}0.017^{*} \\
{[0.009]}\end{array}$ & $\begin{array}{c}0.004 \\
{[0.008]}\end{array}$ & $\begin{array}{c}0.008 \\
{[0.007]}\end{array}$ \\
\hline very competitive college & $\begin{array}{c}0.022 \\
{[0.016]}\end{array}$ & $\begin{array}{c}0.014 \\
{[0.014]}\end{array}$ & $\begin{array}{c}0.013 \\
{[0.012]}\end{array}$ & $\begin{array}{c}0.002 \\
{[0.011]}\end{array}$ \\
\hline unranked college & $\begin{array}{c}0.026 \\
{[0.040]}\end{array}$ & $\begin{array}{c}0.033 \\
{[0.037]}\end{array}$ & $\begin{array}{c}0.000 \\
{[0.027]}\end{array}$ & $\begin{array}{c}0.011 \\
{[0.032]}\end{array}$ \\
\hline Teacher with advanced degree & $\begin{array}{l}-0.023^{* *} \\
{[0.010]}\end{array}$ & $\begin{array}{l}-0.024^{* *} \\
{[0.009]}\end{array}$ & $\begin{array}{l}-0.016^{* *} \\
{[0.008]}\end{array}$ & $\begin{array}{c}-0.018^{* * *} \\
{[0.007]}\end{array}$ \\
\hline Teacher Nat'l Board Certified & $\begin{array}{c}0.012 \\
{[0.023]}\end{array}$ & $\begin{array}{l}0.045^{* *} \\
{[0.020]}\end{array}$ & $\begin{array}{c}-0.004 \\
{[0.018]}\end{array}$ & $\begin{array}{c}0.030^{*} \\
{[0.016]}\end{array}$ \\
\hline Teacher's licensure test score & $\begin{array}{l}0.017^{* * *} \\
{[0.005]}\end{array}$ & $\begin{array}{l}0.010^{* *} \\
{[0.005]}\end{array}$ & $\begin{array}{l}0.012^{* * *} \\
{[0.004]}\end{array}$ & $\begin{array}{c}0.005 \\
{[0.004]}\end{array}$ \\
\hline Class size & $\begin{array}{l}0.006^{* *} \\
{[0.003]}\end{array}$ & $\begin{array}{c}0.005^{*} \\
{[0.003]}\end{array}$ & $\begin{array}{c}0.002 \\
{[0.002]}\end{array}$ & $\begin{array}{c}0.001 \\
{[0.002]}\end{array}$ \\
\hline Student covariates & Yes & Yes & Yes & Yes \\
\hline School fixed effects & Yes & Yes & Yes & Yes \\
\hline Lagged stu dent achiev ement con trols & No & No & Yes & Yes \\
\hline Observations & 61,509 & 61,242 & 60,656 & 60,502 \\
\hline $\mathrm{R}^{2}$ & 0.538 & 0.486 & 0.756 & 0.707 \\
\hline
\end{tabular}


Table 7 Effects of teacher qualifications, with school fixed effects; evenly balanced sc hool subsa mple

\begin{tabular}{|c|c|c|c|c|}
\hline \multirow[b]{2}{*}{ Indepen dent variab le } & \multicolumn{2}{|c|}{ Omitting lagged achievement } & \multicolumn{2}{|c|}{ Including lagged achievement } \\
\hline & Math & Reading & Math & Reading \\
\hline Black teacher & $\begin{array}{c}0.021 \\
{[0.022]}\end{array}$ & $\begin{array}{c}-0.009 \\
{[0.020]}\end{array}$ & $\begin{array}{c}-0.008 \\
{[0.018]}\end{array}$ & $\begin{array}{c}0.005 \\
{[0.016]}\end{array}$ \\
\hline Hispanic teacher & $\begin{array}{c}0.098 \\
{[0.113]}\end{array}$ & $\begin{array}{c}0.056 \\
{[0.070]}\end{array}$ & $\begin{array}{c}-0.084 \\
{[0.094]}\end{array}$ & $\begin{array}{c}0.057 \\
{[0.059]}\end{array}$ \\
\hline Other race teacher & $\begin{array}{c}0.058 \\
{[0.068]}\end{array}$ & $\begin{array}{c}0.042 \\
{[0.056]}\end{array}$ & $\begin{array}{c}-0.054 \\
{[0.057]}\end{array}$ & $\begin{array}{c}0.042 \\
{[0.042]}\end{array}$ \\
\hline Male teacher & $\begin{array}{c}0.012 \\
{[0.022]}\end{array}$ & $\begin{array}{c}-0.022 \\
{[0.018]}\end{array}$ & $\begin{array}{c}-0.006 \\
{[0.018]}\end{array}$ & $\begin{array}{c}-0.011 \\
{[0.013]}\end{array}$ \\
\hline \multicolumn{5}{|l|}{ Teacher exp erience $($ base $=0$ yea rs $)$} \\
\hline 1-2 years experience & $\begin{array}{c}0.049 * * \\
{[0.023]}\end{array}$ & $\begin{array}{c}0.001 \\
{[0.022]}\end{array}$ & $\begin{array}{c}0.066 * * * \\
{[0.020]}\end{array}$ & $\begin{array}{c}0.017 \\
{[0.017]}\end{array}$ \\
\hline 3-5 years experience & $\begin{array}{c}0.078 * * * \\
{[0.025]}\end{array}$ & $\begin{array}{c}0.035 \\
{[0.022]}\end{array}$ & $\begin{array}{c}0.080 * * * \\
{[0.021]}\end{array}$ & $\begin{array}{c}0.035 * \\
{[0.018]}\end{array}$ \\
\hline $6-12$ years experience & $\begin{array}{c}0.055 * * \\
{[0.025]}\end{array}$ & $\begin{array}{c}0.034 \\
{[0.022]}\end{array}$ & $\begin{array}{c}0.085 * * * \\
{[0.020]}\end{array}$ & $\begin{array}{c}0.064 * * * \\
{[0.018]}\end{array}$ \\
\hline 13-20 years experience & $\begin{array}{c}0.081 * * * \\
{[0.026]}\end{array}$ & $\begin{array}{c}0.037 \\
{[0.024]}\end{array}$ & $\begin{array}{c}0.113 * * * \\
{[0.022]}\end{array}$ & $\begin{array}{c}0.073 * * * \\
{[0.019]}\end{array}$ \\
\hline 20-27 years experience & $\begin{array}{c}0.084 * * * \\
{[0.024]}\end{array}$ & $\begin{array}{c}0.064 * * * \\
{[0.022]}\end{array}$ & $\begin{array}{c}0.101 * * * \\
{[0.021]}\end{array}$ & $\begin{array}{c}0.080 * * * \\
{[0.018]}\end{array}$ \\
\hline$>27$ years experience & $\begin{array}{c}0.108 * * * \\
{[0.028]}\end{array}$ & $\begin{array}{c}0.070 * * * \\
{[0.024]}\end{array}$ & $\begin{array}{c}0.130 * * * \\
{[0.023]}\end{array}$ & $\begin{array}{c}0.095 * * * \\
{[0.020]}\end{array}$ \\
\hline \multicolumn{5}{|c|}{ Quality of teacher's college (base $=$ less competitive) } \\
\hline competitive college & $\begin{array}{c}-0.011 \\
{[0.014]}\end{array}$ & $\begin{array}{c}0.01 \\
{[0.012]}\end{array}$ & $\begin{array}{c}-0.013 \\
{[0.012]}\end{array}$ & $\begin{array}{c}0.006 \\
{[0.010]}\end{array}$ \\
\hline very competitive college & $\begin{array}{c}-0.023 \\
{[0.024]}\end{array}$ & $\begin{array}{c}-0.002 \\
{[0.019]}\end{array}$ & $\begin{array}{c}-0.005 \\
{[0.020]}\end{array}$ & $\begin{array}{c}0.009 \\
{[0.014]}\end{array}$ \\
\hline unranked college & $\begin{array}{c}-0.022 \\
{[0.058]}\end{array}$ & $\begin{array}{c}0.072 \\
{[0.053]}\end{array}$ & $\begin{array}{c}-0.067 * \\
{[0.039]}\end{array}$ & $\begin{array}{c}0.027 \\
{[0.041]}\end{array}$ \\
\hline Teacher with advanced degree & $\begin{array}{c}-0.023 \\
{[0.014]}\end{array}$ & $\begin{array}{c}-0.009 \\
{[0.013]}\end{array}$ & $\begin{array}{c}-0.023 * * \\
{[0.012]}\end{array}$ & $\begin{array}{c}-0.007 \\
{[0.010]}\end{array}$ \\
\hline Teacher Nat'l Board Certified & $\begin{array}{c}-0.044 \\
{[0.032]}\end{array}$ & $\begin{array}{c}-0.004 \\
{[0.025]}\end{array}$ & $\begin{array}{c}-0.035 \\
{[0.028]}\end{array}$ & $\begin{array}{c}0.005 \\
{[0.023]}\end{array}$ \\
\hline Teacher's licensure test score & $\begin{array}{l}0.012 * \\
{[0.007]}\end{array}$ & $\begin{array}{c}0.001 \\
{[0.007]}\end{array}$ & $\begin{array}{c}0.012 * \\
{[0.006]}\end{array}$ & $\begin{array}{c}0.002 \\
{[0.006]}\end{array}$ \\
\hline Class size & $\begin{array}{c}0.008 \\
{[0.005]}\end{array}$ & $\begin{array}{c}0.003 \\
{[0.005]}\end{array}$ & $\begin{array}{c}0.006 \\
{[0.004]}\end{array}$ & $\begin{array}{c}0.002 \\
{[0.003]}\end{array}$ \\
\hline Student covariates & Yes & Yes & Yes & Yes \\
\hline School fixed effects & Yes & Yes & Yes & Yes \\
\hline Lagged stu dent achiev ement con trols & No & No & Yes & Yes \\
\hline Observations & 25,147 & 25,045 & 24,768 & 24,711 \\
\hline $\mathrm{R}^{2}$ & 0.553 & 0.496 & 0.766 & 0.708 \\
\hline
\end{tabular}

Note: stand ard errors, in square brackets, have been corrected for within-classroom clustering. ${ }^{*}, * *$, and ${ }^{* * *}$ d enote significance at the $10 \%, 5 \%$ and $1 \%$ levels. Demographic controls include gender, race, and free/reduced price lunch status. Extended set of controls includes categorical measures of computer use, time spent free reading, time spent watching TV, parental education, and time spent on homework. Sample is restricted to the 521 elementary schools for which chi-square tests fail to reject the hypothesis of random assignment along six dimensions: race, gender, parent education, prior year test score, whether a student attended the same school in the previous year, and free/reduce d price lunch receipt. 
Table 8: Do teacher qualification effects vary across students?

\begin{tabular}{|c|c|c|c|c|c|c|}
\hline \multirow{2}{*}{$\begin{array}{l}\text { Student characteristics: } \\
\text { Teacher cred entials: }\end{array}$} & \multicolumn{2}{|c|}{$\begin{array}{l}\text { Free/reduced price } \\
\text { lunch: no }=1\end{array}$} & \multicolumn{2}{|c|}{$\begin{array}{c}\text { Parent ed ucation: } \\
\text { high }=1\end{array}$} & \multicolumn{2}{|c|}{$\begin{array}{l}4^{\text {th }} \text { grade test score: } \\
\text { above average }=1\end{array}$} \\
\hline & Math & Reading & Math & Reading & Math & Reading \\
\hline Black teacher & $\begin{array}{l}-0.019 \\
{[0.023]}\end{array}$ & $\begin{array}{c}0.002 \\
{[0.026]}\end{array}$ & $\begin{array}{l}-0.041^{*} \\
{[0.023]}\end{array}$ & $\begin{array}{c}0.002 \\
{[0.028]}\end{array}$ & $\begin{array}{l}-0.038 \\
{[0.028]}\end{array}$ & $\begin{array}{l}-0.013 \\
{[0.032]}\end{array}$ \\
\hline Hispanic teacher & $\begin{array}{l}-0.059 \\
{[0.097]}\end{array}$ & $\begin{array}{l}-0.016 \\
{[0.200]}\end{array}$ & $\begin{array}{c}-0.084 \\
{[0.085]}\end{array}$ & $\begin{array}{l}-0.102 \\
{[0.163]}\end{array}$ & $\begin{array}{l}-0.221^{* *} \\
{[0.060]}\end{array}$ & $\begin{array}{r}-0.234^{* * *} \\
{[0.109]}\end{array}$ \\
\hline Other race teacher & $\begin{array}{l}-0.065 \\
{[0.061]}\end{array}$ & $\begin{array}{c}0.009 \\
{[0.102]}\end{array}$ & $\begin{array}{l}-0.178^{* *} \\
{[0.078]}\end{array}$ & $\begin{array}{l}-0.091 \\
{[0.072]}\end{array}$ & $\begin{array}{c}0.071 \\
{[0.081]}\end{array}$ & $\begin{array}{c}0.164 \\
{[0.111]}\end{array}$ \\
\hline Male teacher & $\begin{array}{c}0.010 \\
{[0.029]}\end{array}$ & $\begin{array}{c}0.010 \\
{[0.029]}\end{array}$ & $\begin{array}{c}0.014 \\
{[0.024]}\end{array}$ & $\begin{array}{l}-0.022 \\
{[0.026]}\end{array}$ & $\begin{array}{c}0.020 \\
{[0.031]}\end{array}$ & $\begin{array}{c}0.013 \\
{[0.035]}\end{array}$ \\
\hline \multicolumn{7}{|c|}{ Teacher experience (base is no experience) } \\
\hline $1-2$ years & $\begin{array}{c}0.021 \\
{[0.032]}\end{array}$ & $\begin{array}{c}0.012 \\
{[0.038]}\end{array}$ & $\begin{array}{c}0.039 \\
{[0.029]}\end{array}$ & $\begin{array}{l}-0.016 \\
{[0.036]}\end{array}$ & $\begin{array}{c}0.021 \\
{[0.037]}\end{array}$ & $\begin{array}{l}-0.039 \\
{[0.042]}\end{array}$ \\
\hline $3-5$ years & $\begin{array}{c}0.038 \\
{[0.032]}\end{array}$ & $\begin{array}{c}0.050 \\
{[0.036]}\end{array}$ & $\begin{array}{c}0.033 \\
{[0.029]}\end{array}$ & $\begin{array}{l}-0.043 \\
{[0.034]}\end{array}$ & $\begin{array}{c}0.057 \\
{[0.036]}\end{array}$ & $\begin{array}{l}-0.041 \\
{[0.039]}\end{array}$ \\
\hline $6-12$ years & $\begin{array}{c}0.015 \\
{[0.029]}\end{array}$ & $\begin{array}{c}0.018 \\
{[0.035]}\end{array}$ & $\begin{array}{c}0.041 \\
{[0.028]}\end{array}$ & $\begin{array}{c}-0.011 \\
{[0.033]}\end{array}$ & $\begin{array}{c}0.042 \\
{[0.035]}\end{array}$ & $\begin{array}{c}-0.055 \\
{[0.038]}\end{array}$ \\
\hline $13-20$ years & $\begin{array}{c}0.030 \\
{[0.031]}\end{array}$ & $\begin{array}{c}0.020 \\
{[0.037]}\end{array}$ & $\begin{array}{c}0.055^{*} \\
{[0.029]}\end{array}$ & $\begin{array}{c}-0.026 \\
{[0.035]}\end{array}$ & $\begin{array}{c}0.026 \\
{[0.037]}\end{array}$ & $\begin{array}{c}-0.091 \\
{[0.041]}\end{array}$ \\
\hline $20-27$ years & $\begin{array}{l}0.062^{* *} \\
{[0.030]}\end{array}$ & $\begin{array}{c}-0.003 \\
{[0.036]}\end{array}$ & $\begin{array}{l}0.083^{* * *} \\
{[0.029]}\end{array}$ & $\begin{array}{c}-0.028 \\
{[0.035]}\end{array}$ & $\begin{array}{c}0.053 \\
{[0.036]}\end{array}$ & $\begin{array}{c}-0.052^{* *} \\
{[0.041]}\end{array}$ \\
\hline$>27$ years & $\begin{array}{c}0.063^{*} \\
{[0.034]}\end{array}$ & $\begin{array}{c}0.054 \\
{[0.040]}\end{array}$ & $\begin{array}{l}0.068^{* *} \\
{[0.034]}\end{array}$ & $\begin{array}{c}-0.004 \\
{[0.037]}\end{array}$ & $\begin{array}{c}0.046 \\
{[0.042]}\end{array}$ & $\begin{array}{c}-0.012 \\
{[0.042]}\end{array}$ \\
\hline \multicolumn{7}{|c|}{ Quality of undergraduate institution (Base is less competitive college) } \\
\hline competitive college & $\begin{array}{c}0.022 \\
{[0.016]}\end{array}$ & $\begin{array}{c}-0.017 \\
{[0.017]}\end{array}$ & $\begin{array}{c}0.015 \\
{[0.016]}\end{array}$ & $\begin{array}{c}-0.014 \\
{[0.017]}\end{array}$ & $\begin{array}{l}0.048^{* *} \\
{[0.019]}\end{array}$ & $\begin{array}{c}0.030 \\
{[0.021]}\end{array}$ \\
\hline very competitive college & $\begin{array}{c}-0.021 \\
{[0.029]}\end{array}$ & $\begin{array}{c}-0.019 \\
{[0.027]}\end{array}$ & $\begin{array}{c}-0.003 \\
{[0.028]}\end{array}$ & $\begin{array}{c}0.002 \\
{[0.025]}\end{array}$ & $\begin{array}{c}-0.027 \\
{[0.031]}\end{array}$ & $\begin{array}{c}-0.019 \\
{[0.033]}\end{array}$ \\
\hline unranked college & $\begin{array}{l}0.163^{* * *} \\
{[0.061]}\end{array}$ & $\begin{array}{c}0.019 \\
{[0.064]}\end{array}$ & $\begin{array}{c}0.095^{*} \\
{[0.049]}\end{array}$ & $\begin{array}{c}-0.013 \\
{[0.056]}\end{array}$ & $\begin{array}{c}0.111^{*} \\
{[0.061]}\end{array}$ & $\begin{array}{c}0.031 \\
{[0.077]}\end{array}$ \\
\hline Teacher Nat'l Board Certified & $\begin{array}{c}0.040 \\
{[0.035]}\end{array}$ & $\begin{array}{c}0.001 \\
{[0.048]}\end{array}$ & $\begin{array}{c}-0.027 \\
{[0.032]}\end{array}$ & $\begin{array}{c}0.029 \\
{[0.041]}\end{array}$ & $\begin{array}{c}-0.031 \\
{[0.054]}\end{array}$ & $\begin{array}{c}0.001 \\
{[0.063]}\end{array}$ \\
\hline Teacher with advanced degree & $\begin{array}{c}0.010 \\
{[0.017]}\end{array}$ & $\begin{array}{c}0.003 \\
{[0.018]}\end{array}$ & $\begin{array}{c}0.009 \\
{[0.018]}\end{array}$ & $\begin{array}{c}0.004 \\
{[0.018]}\end{array}$ & $\begin{array}{c}-0.005 \\
{[0.021]}\end{array}$ & $\begin{array}{c}0.026 \\
{[0.021]}\end{array}$ \\
\hline Teacher's licensure test score & $\begin{array}{c}0.002 \\
{[0.009]}\end{array}$ & $\begin{array}{c}-0.002 \\
{[0.009]}\end{array}$ & $\begin{array}{c}0.003 \\
{[0.009]}\end{array}$ & $\begin{array}{c}-0.014 \\
{[0.009]}\end{array}$ & $\begin{array}{c}0.016 \\
{[0.011]}\end{array}$ & $\begin{array}{c}0.014 \\
{[0.012]}\end{array}$ \\
\hline $\mathrm{N}$ & 24,768 & 24,711 & 24,970 & 24,912 & 25,147 & 25.045 \\
\hline $\mathrm{R}^{2}$ & 0.766 & 0.708 & 0.765 & 0.707 & 0.654 & 0.590 \\
\hline
\end{tabular}

Note: Table entries are coefficients on the interaction terms between the teacher characteristic listed in the first column and the student characteristic named at the top of each row. Standard errors, in square brackets, have been corrected for within-classroom clustering. *, **, and $* * *$ denote significance at the $10 \%, 5 \%$ and $1 \%$ levels. Sample is restricted to the 521 elementary schools for which chi-square tests fail to reject the hypothesis ofrandom assignment along six dimensions: race, gender, parent education, prior year test score, whether a student attended the same school in the previous year, and free/reduced price lunch receipt. Regressions also control for all covariates used in Table 7, including school fixed effects and lagged achievement. 
Figure 1: Distribution of $p$-values for parent education chi-squared tests

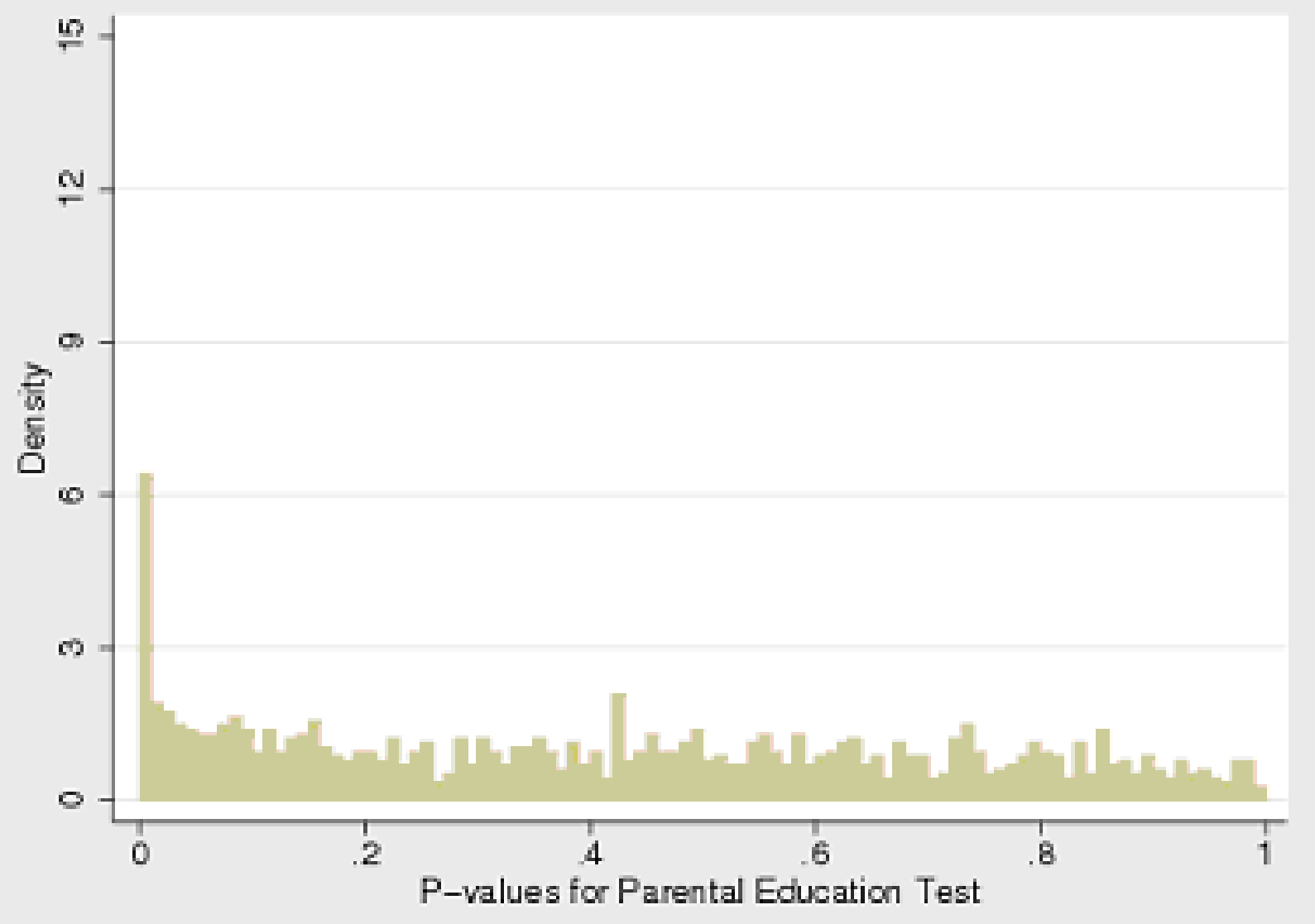


Figure 2: Distribution of $p$-values for race chi-squared tests.

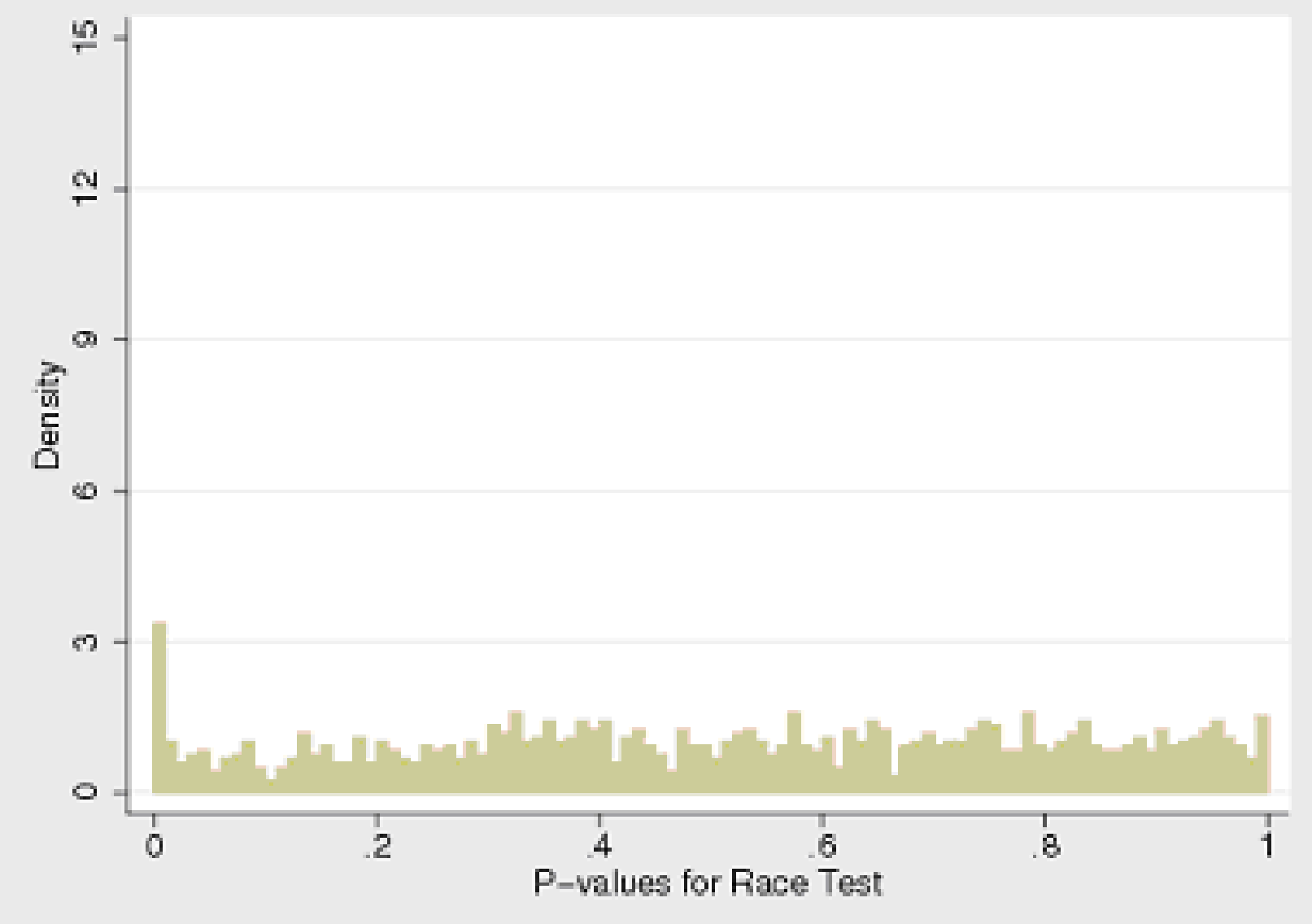


Figure 3: Distribution of $p$-values for subsidized lunch chi-square tests.

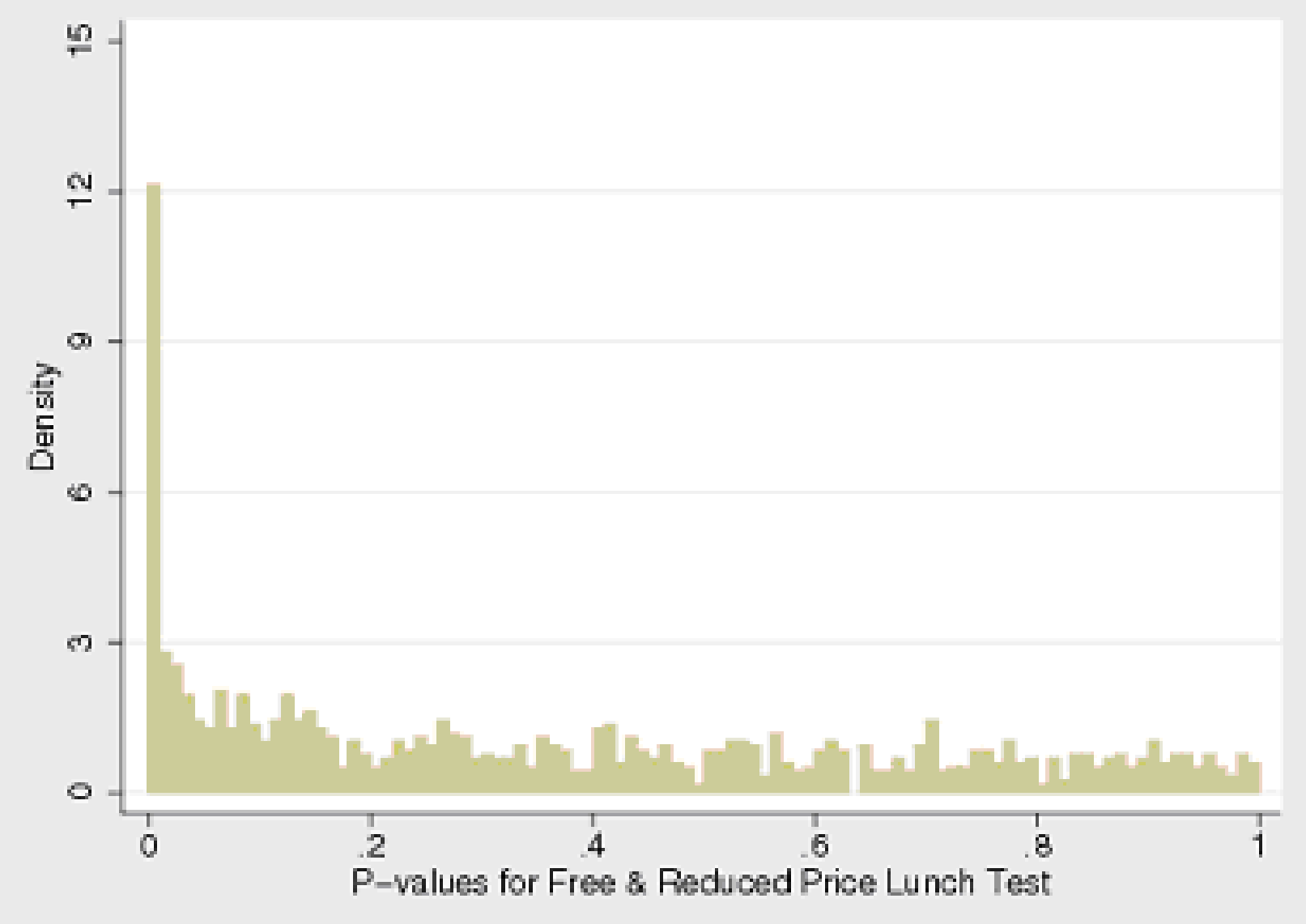


Table A1: Coefficients on student-level covariates, Table 6 specifications

\begin{tabular}{|c|c|c|c|c|}
\hline Indepen dent Variable & Math & Reading & Math & Reading \\
\hline Male & $\begin{array}{l}0.074^{* * *} \\
{[0.006]}\end{array}$ & $\begin{array}{c}-0.030^{* * *} \\
{[0.006]}\end{array}$ & $\begin{array}{l}0.065^{* * *} \\
{[0.004]}\end{array}$ & $\begin{array}{c}-0.040^{* * *} \\
{[0.005]}\end{array}$ \\
\hline Black & $\begin{array}{c}-0.328^{* * *} \\
{[0.008]}\end{array}$ & $\begin{array}{c}-0.323^{* * *} \\
{[0.009]}\end{array}$ & $\begin{array}{c}-0.059^{* * *} \\
{[0.006]}\end{array}$ & $\begin{array}{c}-0.052^{* * *} \\
{[0.007]}\end{array}$ \\
\hline Hispanic & $\begin{array}{r}-0.026 \\
{[0.018]}\end{array}$ & $\begin{array}{r}-0.013 \\
{[0.020]}\end{array}$ & $\begin{array}{c}0.026^{* *} \\
{[0.013]}\end{array}$ & $\begin{array}{l}0.046^{* * *} \\
{[0.015]}\end{array}$ \\
\hline Other & $\begin{array}{c}0.021 \\
{[0.017]}\end{array}$ & $\begin{array}{c}-0.053^{* * *} \\
{[0.016]}\end{array}$ & $\begin{array}{l}0.063^{* * *} \\
{[0.012]}\end{array}$ & $\begin{array}{r}-0.007 \\
{[0.012]}\end{array}$ \\
\hline Gifted & $\begin{array}{l}1.038^{* * *} \\
{[0.009]}\end{array}$ & $\begin{array}{l}0.782^{* * *} \\
{[0.008]}\end{array}$ & $\begin{array}{l}0.336^{* * *} \\
{[0.008]}\end{array}$ & $\begin{array}{l}0.078^{* * *} \\
{[0.007]}\end{array}$ \\
\hline Handicapped & $\begin{array}{c}-0.457^{* * *} \\
{[0.011]}\end{array}$ & $\begin{array}{c}-0.645^{* * *} \\
{[0.013]}\end{array}$ & $\begin{array}{c}0.018^{* *} \\
{[0.008]}\end{array}$ & $\begin{array}{c}-0.166^{* * *} \\
{[0.009]}\end{array}$ \\
\hline Limited English proficient & $\begin{array}{l}-0.254^{* * *} \\
{[0.026]}\end{array}$ & $\begin{array}{c}-0.550^{* * *} \\
{[0.031]}\end{array}$ & $\begin{array}{l}0.079^{* * *} \\
{[0.020]}\end{array}$ & $\begin{array}{l}-0.153^{* * *} \\
{[0.025]}\end{array}$ \\
\hline Free/reduced price lunch recipient & $\begin{array}{c}-0.139^{* * *} \\
{[0.008]}\end{array}$ & $\begin{array}{c}-0.174^{* * *} \\
{[0.008]}\end{array}$ & $\begin{array}{c}-0.027^{* * *} \\
{[0.005]}\end{array}$ & $\begin{array}{c}-0.061^{* * *} \\
{[0.006]}\end{array}$ \\
\hline Repeated grade & $\begin{array}{l}-0.215^{* * *} \\
{[0.025]}\end{array}$ & $\begin{array}{l}-0.261^{* * *} \\
{[0.031]}\end{array}$ & $\begin{array}{l}-0.636^{* * *} \\
{[0.025]}\end{array}$ & $\begin{array}{c}-0.676^{* * *} \\
{[0.028]}\end{array}$ \\
\hline \multicolumn{5}{|c|}{ Lagged parental education(omitted=no HS diploma) } \\
\hline High school diplom a only & $\begin{array}{l}0.228^{* * *} \\
{[0.010]}\end{array}$ & $\begin{array}{l}0.298^{* * *} \\
{[0.012]}\end{array}$ & $\begin{array}{l}0.038^{* * *} \\
{[0.008]}\end{array}$ & $\begin{array}{l}0.105^{* * *} \\
{[0.009]}\end{array}$ \\
\hline Some post secondary & $\begin{array}{l}0.345^{* * *} \\
{[0.013]}\end{array}$ & $\begin{array}{l}0.434^{* * *} \\
{[0.015]}\end{array}$ & $\begin{array}{l}0.059^{* * *} \\
{[0.009]}\end{array}$ & $\begin{array}{l}0.145^{* * *} \\
{[0.011]}\end{array}$ \\
\hline College graduate & $\begin{array}{l}0.539^{* * *} \\
{[0.013]}\end{array}$ & $\begin{array}{l}0.593^{* * *} \\
{[0.014]}\end{array}$ & $\begin{array}{l}0.138^{* * *} \\
{[0.009]}\end{array}$ & $\begin{array}{l}0.188^{* * *} \\
{[0.011]}\end{array}$ \\
\hline \multicolumn{5}{|l|}{ Report homework time (omitted $=$ none) } \\
\hline Less than 1 hour per week & $\begin{array}{l}0.199^{* * *} \\
{[0.024]}\end{array}$ & $\begin{array}{l}0.216^{* * *} \\
{[0.029]}\end{array}$ & $\begin{array}{l}0.079^{* * *} \\
{[0.018]}\end{array}$ & $\begin{array}{l}0.088^{* * *} \\
{[0.021]}\end{array}$ \\
\hline 1-3 hours per week & $\begin{array}{l}0.314^{* * *} \\
{[0.024]}\end{array}$ & $\begin{array}{l}0.320^{* * *} \\
{[0.028]}\end{array}$ & $\begin{array}{l}0.123^{* * *} \\
{[0.018]}\end{array}$ & $\begin{array}{l}0.121^{* * *} \\
{[0.021]}\end{array}$ \\
\hline 3-5 hours per week & $\begin{array}{l}0.405^{* * *} \\
{[0.025]}\end{array}$ & $\begin{array}{l}0.366^{* * *} \\
{[0.029]}\end{array}$ & $\begin{array}{l}0.172^{* * *} \\
{[0.019]}\end{array}$ & $\begin{array}{l}0.124^{\text {*** }} \\
{[0.021]}\end{array}$ \\
\hline 5-10 hours per week & $\begin{array}{l}0.455^{* * *} \\
{[0.025]}\end{array}$ & $\begin{array}{l}0.380^{* * *} \\
{[0.029]}\end{array}$ & $\begin{array}{l}0.210^{* * *} \\
{[0.019]}\end{array}$ & $\begin{array}{l}0.128^{* * *} \\
{[0.022]}\end{array}$ \\
\hline More than 10 hours per week & $\begin{array}{l}0.401^{* * *} \\
{[0.029]}\end{array}$ & $\begin{array}{l}0.320^{* * *} \\
{[0.034]}\end{array}$ & $\begin{array}{l}0.216^{* * *} \\
{[0.021]}\end{array}$ & $\begin{array}{l}0.125^{* * *} \\
{[0.025]}\end{array}$ \\
\hline \multicolumn{5}{|c|}{ Reported home PC use (om itted=almost every day): } \\
\hline Once or twice a week & $\begin{array}{l}0.138^{* * *} \\
{[0.014]}\end{array}$ & $\begin{array}{l}0.170^{* * *} \\
{[0.016]}\end{array}$ & $\begin{array}{l}0.036^{* * *} \\
{[0.011]}\end{array}$ & $\begin{array}{l}0.066^{* * *} \\
{[0.012]}\end{array}$ \\
\hline Once or twice a mon th & $\begin{array}{l}0.237^{* * *} \\
{[0.014]}\end{array}$ & $\begin{array}{l}0.264^{* * *} \\
{[0.016]}\end{array}$ & $\begin{array}{l}0.071^{* * *} \\
{[0.010]}\end{array}$ & $\begin{array}{l}0.098^{* * *} \\
{[0.012]}\end{array}$ \\
\hline Hardly ever & $\begin{array}{l}0.171^{* * *} \\
{[0.013]}\end{array}$ & $\begin{array}{l}0.219^{* * *} \\
{[0.015]}\end{array}$ & $\begin{array}{l}0.050^{* * *} \\
{[0.010]}\end{array}$ & $\begin{array}{l}0.097^{\text {*** }} \\
{[0.012]}\end{array}$ \\
\hline Never & $\begin{array}{l}0.137^{* * *} \\
{[0.014]}\end{array}$ & $\begin{array}{l}0.207^{* * *} \\
{[0.016]}\end{array}$ & $\begin{array}{c}0.025^{* *} \\
{[0.010]}\end{array}$ & $\begin{array}{l}0.092^{* * *} \\
{[0.012]}\end{array}$ \\
\hline No computer at home & $\begin{array}{l}0.084^{* * *} \\
{[0.014]}\end{array}$ & $\begin{array}{l}0.150^{* * *} \\
{[0.017]}\end{array}$ & $\begin{array}{c}0.017 \\
{[0.010]}\end{array}$ & $\begin{array}{l}0.084^{* * *} \\
{[0.012]}\end{array}$ \\
\hline \multicolumn{5}{|l|}{ Reported reading time (omitted $=$ none) } \\
\hline 30 minutes per day & $\begin{array}{l}0.088^{* * *} \\
{[0.013]}\end{array}$ & $\begin{array}{l}0.127^{* * *} \\
{[0.014]}\end{array}$ & $\begin{array}{l}0.028^{* * *} \\
{[0.009]}\end{array}$ & $\begin{array}{l}0.067^{* * *} \\
{[0.011]}\end{array}$ \\
\hline
\end{tabular}




\begin{tabular}{|c|c|c|c|c|}
\hline Indepen dent Variable & Math & Reading & Math & Reading \\
\hline 1 hour per day & $\begin{array}{l}0.196^{* * *} \\
{[0.014]}\end{array}$ & $\begin{array}{l}0.259^{* * *} \\
{[0.015]}\end{array}$ & $\begin{array}{l}0.055^{* * *} \\
{[0.010]}\end{array}$ & $\begin{array}{l}0.119^{* * *} \\
{[0.011]}\end{array}$ \\
\hline 1-2 hours per day & $\begin{array}{l}0.261^{* * *} \\
{[0.014]}\end{array}$ & $\begin{array}{l}0.373^{* * *} \\
{[0.016]}\end{array}$ & $\begin{array}{l}0.054^{* * *} \\
{[0.010]}\end{array}$ & $\begin{array}{l}0.165^{* * *} \\
{[0.012]}\end{array}$ \\
\hline More than 2 hours per day & $\begin{array}{l}0.265^{* * *} \\
{[0.016]}\end{array}$ & $\begin{array}{l}0.477^{* * *} \\
{[0.018]}\end{array}$ & $\begin{array}{c}0.009 \\
{[0.011]}\end{array}$ & $\begin{array}{l}0.220^{* * *} \\
{[0.013]}\end{array}$ \\
\hline \multicolumn{5}{|c|}{ Reported TV use (omitted=none): } \\
\hline Less than 1 hour perday & $\begin{array}{l}0.051^{* * *} \\
{[0.014]}\end{array}$ & $\begin{array}{l}0.079^{* * *} \\
{[0.015]}\end{array}$ & $\begin{array}{c}0.003 \\
{[0.010]}\end{array}$ & $\begin{array}{c}0.028^{* *} \\
{[0.011]}\end{array}$ \\
\hline 2 hours per day & $\begin{array}{l}0.122^{* * *} \\
{[0.014]}\end{array}$ & $\begin{array}{l}0.132^{* * *} \\
{[0.015]}\end{array}$ & $\begin{array}{c}0.023^{* *} \\
{[0.011]}\end{array}$ & $\begin{array}{l}0.029^{* * *} \\
{[0.011]}\end{array}$ \\
\hline 3 hours per day & $\begin{array}{l}0.114^{* * *} \\
{[0.015]}\end{array}$ & $\begin{array}{l}0.139^{* * *} \\
{[0.016]}\end{array}$ & $\begin{array}{c}0.009 \\
{[0.011]}\end{array}$ & $\begin{array}{l}0.030^{* * *} \\
{[0.011]}\end{array}$ \\
\hline 4-5 hours per day & $\begin{array}{l}0.117^{* * *} \\
{[0.016]}\end{array}$ & $\begin{array}{l}0.143^{* * *} \\
{[0.017]}\end{array}$ & $\begin{array}{c}0.008 \\
{[0.011]}\end{array}$ & $\begin{array}{c}0.031^{* *} \\
{[0.012]}\end{array}$ \\
\hline 6 hours or more per day & $\begin{array}{c}0.000 \\
{[0.016]}\end{array}$ & $\begin{array}{c}0.040^{* *} \\
{[0.018]}\end{array}$ & $\begin{array}{c}-0.041^{* * *} \\
{[0.012]}\end{array}$ & $\begin{array}{r}-0.007 \\
{[0.013]}\end{array}$ \\
\hline Lagged achievement & --- & --- & $\begin{array}{l}0.752^{* * *} \\
{[0.004]}\end{array}$ & $\begin{array}{l}0.754^{* * *} \\
{[0.004]}\end{array}$ \\
\hline Constant & $\begin{array}{c}-1.201^{* * *} \\
{[0.079]}\end{array}$ & $\begin{array}{c}-1.216^{* * *} \\
{[0.080]}\end{array}$ & $\begin{array}{c}-0.447^{* * *} \\
{[0.051]}\end{array}$ & $\begin{array}{c}-0.442^{* * *} \\
{[0.050]}\end{array}$ \\
\hline
\end{tabular}


Appendix TableA2. Effects of tea cher qualifications, with school fixed effects; schools failing at least on e chisquared test of random assignment across classrooms

\begin{tabular}{|c|c|c|c|c|}
\hline \multirow[b]{2}{*}{ Indepen dent variab le } & \multicolumn{2}{|c|}{ Omitting lagged achievement } & \multicolumn{2}{|c|}{ Including lagged achievement } \\
\hline & Math & Reading & Math & Reading \\
\hline Black teacher & $\begin{array}{c}-0.030 * \\
{[0.018]}\end{array}$ & $\begin{array}{c}-0.023 \\
{[0.017]}\end{array}$ & $\begin{array}{c}-0.018 \\
{[0.015]}\end{array}$ & $\begin{array}{c}-0.014 \\
{[0.012]}\end{array}$ \\
\hline Hispanic teacher & $\begin{array}{c}0.366 * * * \\
{[0.058]}\end{array}$ & $\begin{array}{c}0.279 * * * \\
{[0.046]}\end{array}$ & $\begin{array}{c}0.140 * * * \\
{[0.047]}\end{array}$ & $\begin{array}{c}0.041 \\
{[0.058]}\end{array}$ \\
\hline Other race teacher & $\begin{array}{c}0.042 \\
{[0.055]}\end{array}$ & $\begin{array}{c}0.006 \\
{[0.070]}\end{array}$ & $\begin{array}{c}0.056 \\
{[0.041]}\end{array}$ & $\begin{array}{c}0.009 \\
{[0.039]}\end{array}$ \\
\hline Male teacher & $\begin{array}{c}0.045 * * \\
{[0.018]}\end{array}$ & $\begin{array}{c}-0.016 \\
{[0.018]}\end{array}$ & $\begin{array}{c}0.032 * * \\
{[0.014]}\end{array}$ & $\begin{array}{c}-0.030 * * \\
{[0.012]}\end{array}$ \\
\hline \multicolumn{5}{|l|}{ Teacher exp erience (base $=0$ years) } \\
\hline 1-2 years experience & $\begin{array}{c}0.051 * * \\
{[0.026]}\end{array}$ & $\begin{array}{c}0.059 * * \\
{[0.025]}\end{array}$ & $\begin{array}{c}0.040 * * \\
{[0.020]}\end{array}$ & $\begin{array}{c}0.049 * * * \\
{[0.018]}\end{array}$ \\
\hline 3-5 years experience & $\begin{array}{c}0.069 * * * \\
{[0.024]}\end{array}$ & $\begin{array}{c}0.047 * * \\
{[0.024]}\end{array}$ & $\begin{array}{c}0.072 * * * \\
{[0.020]}\end{array}$ & $\begin{array}{c}0.054 * * * \\
{[0.018]}\end{array}$ \\
\hline 6-12 years experience & $\begin{array}{c}0.086 * * * \\
{[0.025]}\end{array}$ & $\begin{array}{c}0.054 * * \\
{[0.023]}\end{array}$ & $\begin{array}{c}0.071 * * * \\
{[0.019]}\end{array}$ & $\begin{array}{c}0.042 * * \\
{[0.017]}\end{array}$ \\
\hline 13-20 years experience & $\begin{array}{c}0.084 * * * \\
{[0.025]}\end{array}$ & $\begin{array}{c}0.071 * * * \\
{[0.025]}\end{array}$ & $\begin{array}{c}0.075 * * * \\
{[0.019]}\end{array}$ & $\begin{array}{c}0.062 * * * \\
{[0.018]}\end{array}$ \\
\hline 20-27 years experience & $\begin{array}{c}0.103 * * * \\
{[0.024]}\end{array}$ & $\begin{array}{c}0.086 * * * \\
{[0.023]}\end{array}$ & $\begin{array}{c}0.093 * * * \\
{[0.019]}\end{array}$ & $\begin{array}{c}0.079 * * * \\
{[0.017]}\end{array}$ \\
\hline$>27$ years experience & $\begin{array}{c}0.052 * \\
{[0.029]}\end{array}$ & $\begin{array}{c}0.037 \\
{[0.028]}\end{array}$ & $\begin{array}{c}0.062 * * * \\
{[0.022]}\end{array}$ & $\begin{array}{c}0.050 * * \\
{[0.020]}\end{array}$ \\
\hline \multicolumn{5}{|c|}{ Quality of teacher's college (base=less competitive) } \\
\hline very competitive college & $\begin{array}{c}0.050 * * \\
{[0.022]}\end{array}$ & $\begin{array}{c}0.018 \\
{[0.021]}\end{array}$ & $\begin{array}{c}0.025 \\
{[0.016]}\end{array}$ & $\begin{array}{c}-0.008 \\
{[0.015]}\end{array}$ \\
\hline competitive college & $\begin{array}{c}0.027 * * \\
{[0.014]}\end{array}$ & $\begin{array}{c}0.020 \\
{[0.013]}\end{array}$ & $\begin{array}{l}0.017 * \\
{[0.011]}\end{array}$ & $\begin{array}{c}0.008 \\
{[0.009]}\end{array}$ \\
\hline unranked college & $\begin{array}{c}0.054 \\
{[0.055]}\end{array}$ & $\begin{array}{c}-0.016 \\
{[0.050]}\end{array}$ & $\begin{array}{c}0.049 \\
{[0.036]}\end{array}$ & $\begin{array}{c}-0.013 \\
{[0.046]}\end{array}$ \\
\hline Teacher with advanced degree & $\begin{array}{c}-0.021 \\
{[0.014]}\end{array}$ & $\begin{array}{c}-0.032 * * \\
{[0.013]}\end{array}$ & $\begin{array}{c}-0.010 \\
{[0.011]}\end{array}$ & $\begin{array}{c}-0.023 * * \\
{[0.009]}\end{array}$ \\
\hline Teacher Nat'l Board Certified & $\begin{array}{c}0.052 \\
{[0.033]}\end{array}$ & $\begin{array}{c}0.083 * * * \\
{[0.029]}\end{array}$ & $\begin{array}{c}0.017 \\
{[0.025]}\end{array}$ & $\begin{array}{l}0.048 * * \\
{[0.021]}\end{array}$ \\
\hline Teacher's licensure test score & $\begin{array}{c}0.020 * * * \\
{[0.007]}\end{array}$ & $\begin{array}{c}0.016 * * \\
{[0.007]}\end{array}$ & $\begin{array}{c}0.011 * * \\
{[0.006]}\end{array}$ & $\begin{array}{c}0.007 \\
{[0.005]}\end{array}$ \\
\hline Class size & $\begin{array}{c}0.006 * \\
{[0.004]}\end{array}$ & $\begin{array}{c}0.007 * \\
{[0.004]}\end{array}$ & $\begin{array}{c}0.001 \\
{[0.002]}\end{array}$ & $\begin{array}{c}0.001 \\
{[0.002]}\end{array}$ \\
\hline Student covariates & Yes & Yes & Yes & Yes \\
\hline School fixed effects & Yes & Yes & Yes & Yes \\
\hline Lagged stu dent achiev ement con trols & No & No & Yes & Yes \\
\hline Observations & 36,362 & 36,197 & 35,888 & 35,791 \\
\hline $\mathrm{R}^{2}$ & 0.528 & 0.480 & 0.750 & 0.706 \\
\hline
\end{tabular}


Appendix Table A3. Effects of teacher qualifications, with school fixed effects; schools meeting even balance criteria when significance level is $20 \%$

\begin{tabular}{|c|c|c|c|c|}
\hline \multirow[b]{2}{*}{ Indepen dent variab le } & \multicolumn{2}{|c|}{ Omitting lagged achievement } & \multicolumn{2}{|c|}{ Including lagged achievement } \\
\hline & Math & Reading & Math & Reading \\
\hline Black teacher & $\begin{array}{c}-0.034 \\
{[0.028]}\end{array}$ & $\begin{array}{c}-0.034 \\
{[0.024]}\end{array}$ & $\begin{array}{c}-0.010 \\
{[0.024]}\end{array}$ & $\begin{array}{c}-0.008 \\
{[0.020]}\end{array}$ \\
\hline Hispanic teacher & $\begin{array}{c}-0.192 * * * \\
{[0.039]}\end{array}$ & $\begin{array}{c}-0.113 * * * \\
{[0.036]}\end{array}$ & $\begin{array}{c}-0.229 * * * \\
{[0.032]}\end{array}$ & $\begin{array}{c}-0.143 * * * \\
{[0.029]}\end{array}$ \\
\hline Other race teacher & $\begin{array}{l}-0.151 * \\
{[0.088]}\end{array}$ & $\begin{array}{c}0.029 \\
{[0.077]}\end{array}$ & $\begin{array}{l}-0.115 \\
{[0.071]}\end{array}$ & $\begin{array}{c}0.058 \\
{[0.059]}\end{array}$ \\
\hline Male teacher & $\begin{array}{c}0.009 \\
{[0.025]}\end{array}$ & $\begin{array}{l}-0.032 * \\
{[0.018]}\end{array}$ & $\begin{array}{c}0.013 \\
{[0.021]}\end{array}$ & $\begin{array}{l}-0.027 * \\
{[0.015]}\end{array}$ \\
\hline \multicolumn{5}{|l|}{ Teacher exp erience (base $=0$ years $)$} \\
\hline 1-2 years experience & $\begin{array}{c}0.058 * \\
{[0.031]}\end{array}$ & $\begin{array}{c}0.014 \\
{[0.029]}\end{array}$ & $\begin{array}{c}0.071 * * * \\
{[0.026]}\end{array}$ & $\begin{array}{c}0.021 \\
{[0.023]}\end{array}$ \\
\hline 3-5 years experience & $\begin{array}{l}0.070 * * \\
{[0.033]}\end{array}$ & $\begin{array}{c}0.044 \\
{[0.029]}\end{array}$ & $\begin{array}{l}0.069 * * \\
{[0.028]}\end{array}$ & $\begin{array}{c}0.036 \\
{[0.023]}\end{array}$ \\
\hline $6-12$ years experience & $\begin{array}{l}0.073 * * \\
{[0.034]}\end{array}$ & $\begin{array}{c}0.047 \\
{[0.029]}\end{array}$ & $\begin{array}{c}0.096 * * * \\
{[0.028]}\end{array}$ & $\begin{array}{c}0.065 * * * \\
{[0.024]}\end{array}$ \\
\hline 13-20 years experience & $\begin{array}{c}0.112 * * * \\
{[0.037]}\end{array}$ & $\begin{array}{c}0.028 \\
{[0.033]}\end{array}$ & $\begin{array}{c}0.134 * * * \\
{[0.031]}\end{array}$ & $\begin{array}{c}0.048 * \\
{[0.027]}\end{array}$ \\
\hline 20-27 years experience & $\begin{array}{c}0.108 * * * \\
{[0.032]}\end{array}$ & $\begin{array}{c}0.068 * * \\
{[0.028]}\end{array}$ & $\begin{array}{c}0.118 * * * \\
{[0.027]}\end{array}$ & $\begin{array}{c}0.071 * * * \\
{[0.023]}\end{array}$ \\
\hline$>27$ years experience & $\begin{array}{c}0.108 * * * \\
{[0.035]}\end{array}$ & $\begin{array}{c}0.046 \\
{[0.030]}\end{array}$ & $\begin{array}{c}0.138 * * * \\
{[0.030]}\end{array}$ & $\begin{array}{c}0.072 * * * \\
{[0.025]}\end{array}$ \\
\hline \multicolumn{5}{|c|}{ Quality of teacher's college (base=less competitive) } \\
\hline very competitive college & $\begin{array}{l}-0.050 \\
{[0.031]}\end{array}$ & $\begin{array}{l}-0.022 \\
{[0.025]}\end{array}$ & $\begin{array}{l}-0.016 \\
{[0.025]}\end{array}$ & $\begin{array}{c}0.008 \\
{[0.021]}\end{array}$ \\
\hline competitive college & $\begin{array}{c}-0.008 \\
{[0.018]}\end{array}$ & $\begin{array}{c}0.014 \\
{[0.016]}\end{array}$ & $\begin{array}{l}-0.016 \\
{[0.015]}\end{array}$ & $\begin{array}{c}0.008 \\
{[0.013]}\end{array}$ \\
\hline unranked college & $\begin{array}{l}-0.129 \\
{[0.120]}\end{array}$ & $\begin{array}{c}0.055 \\
{[0.107]}\end{array}$ & $\begin{array}{l}-0.127 \\
{[0.078]}\end{array}$ & $\begin{array}{c}0.046 \\
{[0.075]}\end{array}$ \\
\hline Teacher with advanced degree & $\begin{array}{c}-0.008 \\
{[0.017]}\end{array}$ & $\begin{array}{c}0.006 \\
{[0.016]}\end{array}$ & $\begin{array}{c}-0.013 \\
{[0.014]}\end{array}$ & $\begin{array}{c}0.001 \\
{[0.013]}\end{array}$ \\
\hline Teacher Nat'l Board Certified & $\begin{array}{c}-0.057 \\
{[0.039]}\end{array}$ & $\begin{array}{c}-0.004 \\
{[0.035]}\end{array}$ & $\begin{array}{l}-0.056^{*} \\
{[0.034]}\end{array}$ & $\begin{array}{c}-0.003 \\
{[0.031]}\end{array}$ \\
\hline Teacher's licensure test score & $\begin{array}{c}0.009 \\
{[0.010]}\end{array}$ & $\begin{array}{c}-0.005 \\
{[0.009]}\end{array}$ & $\begin{array}{c}0.012 \\
{[0.009]}\end{array}$ & $\begin{array}{c}-0.003 \\
{[0.007]}\end{array}$ \\
\hline Class size & $\begin{array}{c}0.003 \\
{[0.007]}\end{array}$ & $\begin{array}{c}0.005 \\
{[0.006]}\end{array}$ & $\begin{array}{c}0.001 \\
{[0.006]}\end{array}$ & $\begin{array}{c}0.004 \\
{[0.006]}\end{array}$ \\
\hline Student covariates & Yes & Yes & Yes & Yes \\
\hline School fixed effects & Yes & Yes & Yes & Yes \\
\hline Lagged stu dent achiev ement con trols & No & No & Yes & Yes \\
\hline Observations & 14,668 & 14,608 & 14,457 & 14,424 \\
\hline $\mathrm{R}^{2}$ & 0.563 & 0.500 & 0.769 & 0.709 \\
\hline
\end{tabular}


Appendix Table A4. Full set of coefficients for Table 8 regressions

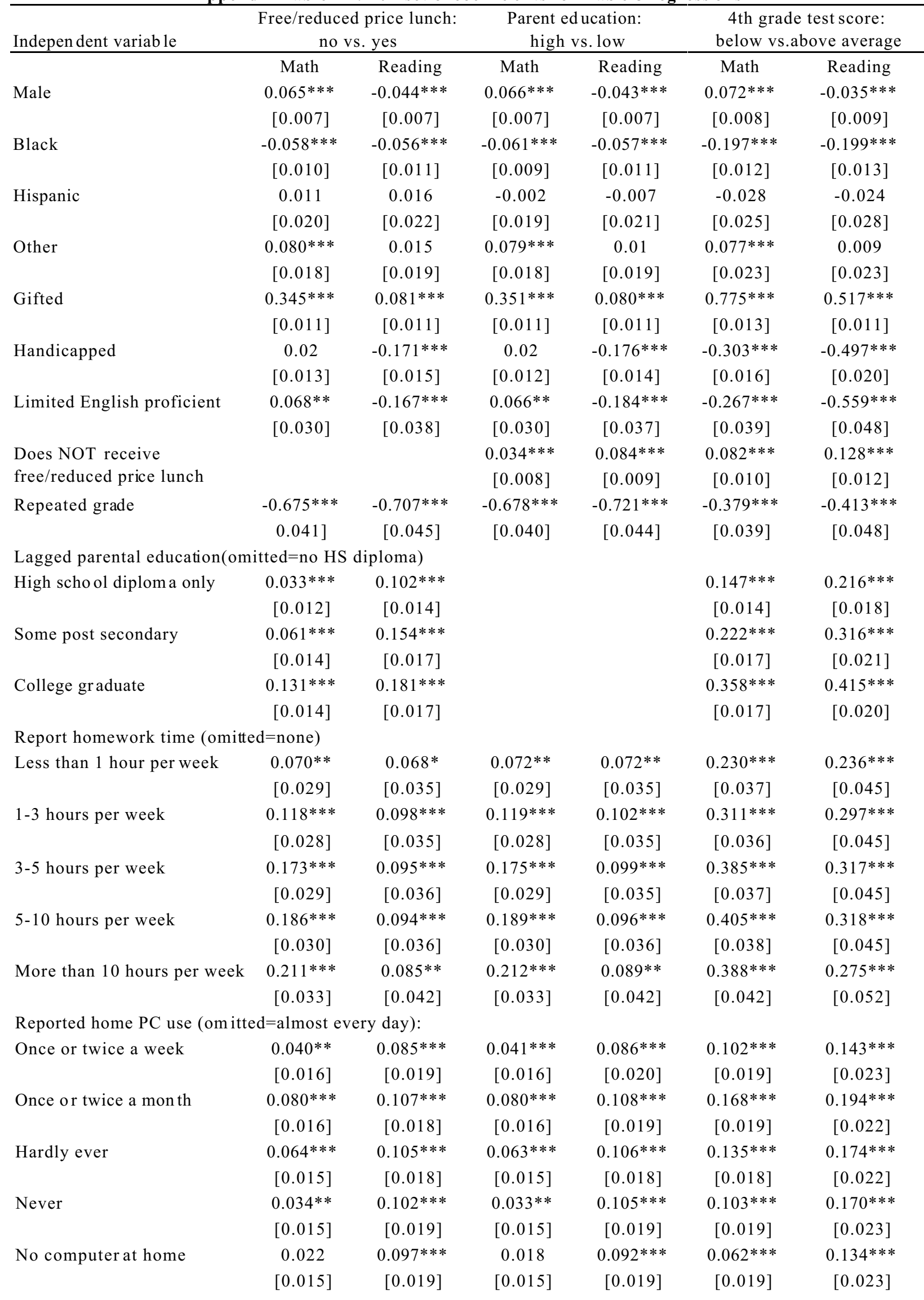




\begin{tabular}{|c|c|c|c|c|c|c|}
\hline \multicolumn{7}{|c|}{ Reported reading time (omitted $=$ none $)$} \\
\hline \multirow[t]{2}{*}{30 minutes per day } & $0.036 * *$ & $0.070 * * *$ & $0.037 * *$ & $0.070 * * *$ & $0.078 * * *$ & $0.112 * * *$ \\
\hline & {$[0.014]$} & {$[0.017]$} & {$[0.014]$} & {$[0.017]$} & {$[0.018]$} & {$[0.020]$} \\
\hline \multirow[t]{2}{*}{1 hour per day } & $0.072 * * *$ & $0.119 * * *$ & $0.074 * * *$ & $0.120 * * *$ & $0.155 * * *$ & $0.200 * * *$ \\
\hline & {$[0.015]$} & {$[0.017]$} & {$[0.015]$} & {$[0.017]$} & {$[0.019]$} & {$[0.021]$} \\
\hline \multirow[t]{2}{*}{ 1-2 hours per day } & $0.066 * * *$ & $0.182 * * *$ & $0.065 * * *$ & $0.183 * * *$ & $0.167 * * *$ & $0.285 * * *$ \\
\hline & {$[0.016]$} & {$[0.018]$} & {$[0.016]$} & {$[0.018]$} & {$[0.020]$} & {$[0.022]$} \\
\hline \multirow[t]{2}{*}{ More than 2 hours per day } & 0.026 & $0.233 * * *$ & 0.025 & $0.234 * * *$ & $0.169 * * *$ & $0.377 * * *$ \\
\hline & {$[0.018]$} & {$[0.021]$} & {$[0.018]$} & {$[0.021]$} & {$[0.022]$} & {$[0.024]$} \\
\hline \multicolumn{7}{|c|}{ Reported TV use (om itted=none): } \\
\hline \multirow[t]{2}{*}{ Less than 1 hour per day } & 0.001 & $0.038 * *$ & -0.003 & $0.038 * *$ & 0.022 & $0.066 * * *$ \\
\hline & {$[0.016]$} & {$[0.017]$} & {$[0.016]$} & {$[0.017]$} & {$[0.020]$} & {$[0.021]$} \\
\hline \multirow[t]{2}{*}{2 hours per day } & $0.029 *$ & $0.058 * * *$ & 0.023 & $0.057 * * *$ & $0.084 * * *$ & $0.120 * * *$ \\
\hline & {$[0.017]$} & {$[0.017]$} & {$[0.017]$} & {$[0.017]$} & {$[0.020]$} & {$[0.021]$} \\
\hline \multirow[t]{2}{*}{3 hours per day } & 0.008 & $0.047 * * *$ & 0.001 & $0.047 * * *$ & $0.061 * * *$ & $0.109 * * *$ \\
\hline & {$[0.017]$} & {$[0.018]$} & {$[0.017]$} & {$[0.018]$} & {$[0.021]$} & {$[0.022]$} \\
\hline \multirow[t]{2}{*}{ 4-5 hours per day } & 0.000 & $0.053 * * *$ & -0.006 & $0.051 * * *$ & $0.061 * * *$ & $0.121 * * *$ \\
\hline & {$[0.018]$} & {$[0.019]$} & {$[0.018]$} & {$[0.019]$} & {$[0.022]$} & {$[0.024]$} \\
\hline \multirow[t]{2}{*}{6 hours or more per day } & $-0.036 *$ & 0.014 & $-0.040 * *$ & 0.014 & -0.004 & $0.050 *$ \\
\hline & [0.019] & {$[0.021]$} & {$[0.019]$} & {$[0.021]$} & {$[0.023]$} & {$[0.026]$} \\
\hline \multirow[t]{2}{*}{ Lagged achievement } & $0.758 * * *$ & $0.752 * * *$ & $0.762 * * *$ & $0.758 * * *$ & & \\
\hline & {$[0.006]$} & {$[0.006]$} & {$[0.006]$} & {$[0.006]$} & & \\
\hline \multirow[t]{2}{*}{ Class size } & $0.008 *$ & 0.003 & $0.007 *$ & 0.002 & 0.002 & 0.000 \\
\hline & {$[0.004]$} & {$[0.004]$} & {$[0.004]$} & {$[0.004]$} & {$[0.005]$} & {$[0.004]$} \\
\hline \multirow[t]{2}{*}{ Black teacher } & -0.016 & 0.006 & -0.034 & 0.007 & 0.008 & 0.009 \\
\hline & {$[0.021]$} & {$[0.021]$} & {$[0.023]$} & {$[0.023]$} & {$[0.023]$} & {$[0.026]$} \\
\hline \multirow[t]{2}{*}{ Hispanic teacher } & -0.100 & 0.063 & -0.098 & 0.029 & 0.096 & $0.249 * * *$ \\
\hline & {$[0.092]$} & {$[0.096]$} & {$[0.077]$} & {$[0.102]$} & {$[0.135]$} & {$[0.088]$} \\
\hline \multirow[t]{2}{*}{ Other race teacher } & -0.071 & 0.042 & $-0.143 * *$ & -0.004 & -0.079 & -0.03 \\
\hline & {$[0.063]$} & {$[0.056]$} & {$[0.065]$} & {$[0.041]$} & {$[0.080]$} & {$[0.104]$} \\
\hline \multirow[t]{2}{*}{ Male teacher } & -0.002 & $-0.031 *$ & 0.006 & -0.023 & -0.022 & -0.028 \\
\hline & {$[0.022]$} & {$[0.017]$} & {$[0.023]$} & {$[0.020]$} & {$[0.025]$} & {$[0.027]$} \\
\hline \multicolumn{7}{|c|}{ Teacher exp erience (base $=0$ yea rs) } \\
\hline \multirow[t]{2}{*}{ 1-2 years experience } & $0.071 * * *$ & 0.021 & $0.092 * * *$ & 0.009 & $0.049 *$ & 0.035 \\
\hline & {$[0.023]$} & {$[0.021]$} & {$[0.026]$} & {$[0.026]$} & {$[0.030]$} & {$[0.034]$} \\
\hline \multirow[t]{2}{*}{ 3-5 years experience } & $0.094 * * *$ & $0.054 * * *$ & $0.103 * * *$ & 0.009 & 0.046 & $0.058^{*}$ \\
\hline & {$[0.024]$} & {$[0.021]$} & {$[0.027]$} & {$[0.026]$} & {$[0.030]$} & {$[0.033]$} \\
\hline $6-12$ years experience & $0.089 * * *$ & $0.071 * * *$ & $0.113 * * *$ & $0.060 * *$ & 0.046 & $0.077 * *$ \\
\hline & {$[0.023]$} & {$[0.021]$} & {$[0.027]$} & {$[0.025]$} & {$[0.030]$} & {$[0.033]$} \\
\hline 13-20 years experience & $0.122 * * *$ & $0.080 * * *$ & $0.149 * * *$ & $0.061 * *$ & $0.082 * * *$ & $0.103 * * *$ \\
\hline & {$[0.025]$} & {$[0.023]$} & {$[0.029]$} & {$[0.027]$} & {$[0.032]$} & {$[0.035]$} \\
\hline 20-27 years experience & $0.123 * * *$ & $0.078 * * *$ & $0.153 * * *$ & $0.065 * *$ & $0.072 * *$ & $0.107 * * *$ \\
\hline & {$[0.024]$} & {$[0.021]$} & {$[0.027]$} & {$[0.026]$} & {$[0.030]$} & {$[0.033]$} \\
\hline$>27$ years experience & $0.152 * * *$ & $0.116^{* * *}$ & $0.173 * * *$ & $0.096 * * *$ & $0.100 * * *$ & $0.096 * * *$ \\
\hline & {$[0.027]$} & {$[0.024]$} & {$[0.031]$} & {$[0.027]$} & {$[0.034]$} & {$[0.035]$} \\
\hline Quality of teacher's college & $\mathrm{se}=$ less con & titive) & & & & \\
\hline very competitive college & -0.012 & 0.003 & -0.005 & 0.010 & 0.000 & 0.016 \\
\hline & {$[0.023]$} & {$[0.017]$} & {$[0.025]$} & {$[0.019]$} & {$[0.026]$} & {$[0.026]$} \\
\hline competitive college & -0.005 & -0.001 & -0.006 & -0.004 & $-0.037 * *$ & -0.005 \\
\hline & {$[0.013]$} & {$[0.012]$} & {$[0.015]$} & {$[0.014]$} & {$[0.016]$} & {$[0.017]$} \\
\hline unranked college & -0.008 & 0.033 & -0.025 & 0.013 & -0.104 & 0.036 \\
\hline
\end{tabular}




\begin{tabular}{|c|c|c|c|c|c|c|}
\hline & {$[0.036]$} & {$[0.041]$} & {$[0.038]$} & {$[0.036]$} & {$[0.069]$} & {$[0.077]$} \\
\hline \multirow{2}{*}{$\begin{array}{l}\text { Teacher with advanced } \\
\text { degree }\end{array}$} & -0.020 & -0.004 & -0.018 & -0.005 & -0.018 & -0.020 \\
\hline & {$[0.014]$} & {$[0.012]$} & {$[0.015]$} & {$[0.014]$} & {$[0.016]$} & {$[0.017]$} \\
\hline \multirow{2}{*}{$\begin{array}{l}\text { Teacher Nat'1 Board } \\
\text { Certified }\end{array}$} & -0.022 & 0.006 & -0.055 & 0.019 & -0.030 & -0.007 \\
\hline & {$[0.033]$} & {$[0.029]$} & {$[0.034]$} & {$[0.032]$} & {$[0.040]$} & {$[0.044]$} \\
\hline \multirow[t]{2}{*}{ Teacher's licensure test score } & $0.013 *$ & 0.001 & $0.015 *$ & -0.006 & 0.008 & -0.001 \\
\hline & {$[0.007]$} & {$[0.007]$} & {$[0.008]$} & {$[0.008]$} & {$[0.009]$} & {$[0.010]$} \\
\hline \multirow[t]{2}{*}{ subgroup dummy } & $-0.097 *$ & 0.036 & 0.024 & -0.100 & $0.522 * * *$ & $0.657 * * *$ \\
\hline & {$[0.059]$} & {$[0.069]$} & {$[0.059]$} & {$[0.066]$} & {$[0.074]$} & {$[0.000]$} \\
\hline \multicolumn{7}{|c|}{ Interactions with subgroup dummy } \\
\hline \multirow[t]{2}{*}{ Class size } & 0.003 & 0.001 & -0.002 & 0.000 & $0.009 * * *$ & $0.005 *$ \\
\hline & {$[0.002]$} & {$[0.003]$} & {$[0.002]$} & {$[0.003]$} & {$[0.003]$} & {$[0.003]$} \\
\hline \multirow[t]{2}{*}{ Black teacher } & -0.019 & 0.002 & $0.041 *$ & -0.002 & -0.038 & -0.013 \\
\hline & {$[0.023]$} & {$[0.026]$} & {$[0.023]$} & {$[0.028]$} & {$[0.028]$} & {$[0.032]$} \\
\hline \multirow[t]{2}{*}{ Hispanic teacher } & -0.059 & -0.016 & 0.084 & 0.102 & $-0.221 * * *$ & $-0.234 * *$ \\
\hline & {$[0.097]$} & {$[0.200]$} & {$[0.085]$} & {$[0.163]$} & {$[0.060]$} & {$[0.109]$} \\
\hline \multirow[t]{2}{*}{ Other race teacher } & -0.065 & 0.009 & $0.178 * *$ & 0.091 & 0.071 & 0.164 \\
\hline & {$[0.061]$} & {$[0.102]$} & {$[0.078]$} & {$[0.072]$} & {$[0.081]$} & [0.111] \\
\hline \multirow[t]{2}{*}{ Male teacher } & 0.010 & $-0.050 *$ & -0.014 & 0.022 & 0.02 & 0.013 \\
\hline & {$[0.029]$} & {$[0.029]$} & {$[0.024]$} & {$[0.026]$} & {$[0.031]$} & {$[0.035]$} \\
\hline \multicolumn{7}{|c|}{ Teacher exp erience (base $=0$ years) } \\
\hline \multirow[t]{2}{*}{ 1-2 years experience } & 0.021 & 0.012 & -0.039 & 0.016 & 0.021 & -0.039 \\
\hline & {$[0.032]$} & {$[0.038]$} & [0.029] & {$[0.036]$} & {$[0.037]$} & {$[0.042]$} \\
\hline \multirow[t]{2}{*}{ 3-5 years experience } & 0.038 & 0.05 & -0.033 & 0.043 & 0.057 & -0.041 \\
\hline & {$[0.032]$} & {$[0.036]$} & {$[0.029]$} & {$[0.034]$} & {$[0.036]$} & {$[0.039]$} \\
\hline \multirow[t]{2}{*}{$6-12$ years experience } & 0.015 & 0.018 & -0.041 & 0.011 & 0.042 & -0.055 \\
\hline & {$[0.029]$} & {$[0.035]$} & {$[0.028]$} & {$[0.033]$} & {$[0.035]$} & {$[0.038]$} \\
\hline \multirow[t]{2}{*}{ 13-20 years experience } & 0.030 & 0.02 & $-0.055^{*}$ & 0.026 & 0.026 & $-0.091 * *$ \\
\hline & {$[0.031]$} & {$[0.037]$} & {$[0.029]$} & {$[0.035]$} & {$[0.037]$} & {$[0.041]$} \\
\hline \multirow[t]{2}{*}{ 20-27 years experience } & $0.062 * *$ & -0.003 & $-0.083 * * *$ & 0.028 & 0.053 & -0.052 \\
\hline & {$[0.030]$} & {$[0.036]$} & {$[0.029]$} & {$[0.035]$} & {$[0.036]$} & {$[0.041]$} \\
\hline \multirow[t]{2}{*}{$>27$ years experience } & $0.063 *$ & 0.054 & $-0.068 * *$ & 0.004 & 0.046 & -0.012 \\
\hline & {$[0.034]$} & {$[0.040]$} & {$[0.034]$} & {$[0.037]$} & {$[0.042]$} & {$[0.042]$} \\
\hline \multicolumn{7}{|c|}{ Quality of teacher's college (base $=$ less competitive) } \\
\hline \multirow[t]{2}{*}{ very competitive college } & -0.021 & -0.019 & 0.003 & -0.002 & -0.027 & -0.019 \\
\hline & {$[0.029]$} & {$[0.027]$} & {$[0.028]$} & {$[0.025]$} & {$[0.031]$} & {$[0.033]$} \\
\hline \multirow[t]{2}{*}{ competitive college } & 0.022 & -0.017 & -0.015 & 0.014 & $0.048 * *$ & 0.030 \\
\hline & {$[0.016]$} & {$[0.017]$} & {$[0.016]$} & {$[0.017]$} & {$[0.019]$} & {$[0.021]$} \\
\hline \multirow[t]{2}{*}{ unranked college } & $0.163 * * *$ & 0.019 & $-0.095 *$ & 0.013 & $0.111 *$ & 0.031 \\
\hline & {$[0.061]$} & {$[0.064]$} & {$[0.049]$} & {$[0.056]$} & {$[0.061]$} & {$[0.077]$} \\
\hline \multirow{2}{*}{$\begin{array}{l}\text { Teacher with advanced } \\
\text { degree }\end{array}$} & 0.010 & 0.003 & -0.009 & -0.004 & -0.005 & 0.026 \\
\hline & {$[0.017]$} & {$[0.018]$} & {$[0.018]$} & {$[0.018]$} & {$[0.021]$} & {$[0.021]$} \\
\hline Teacher Nat'l Board & 0.040 & 0.001 & 0.027 & -0.029 & -0.031 & 0.001 \\
\hline Certified & {$[0.035]$} & {$[0.048]$} & {$[0.032]$} & {$[0.041]$} & {$[0.054]$} & [0.063] \\
\hline Teacher's licensure test score & 0.002 & -0.002 & -0.003 & 0.014 & 0.016 & 0.014 \\
\hline & {$[0.009]$} & {$[0.009]$} & {$[0.009]$} & {$[0.009]$} & {$[0.011]$} & {$[0.012]$} \\
\hline Observations & 24,768 & 24,711 & 24,970 & 24,912 & 25,147 & 25,045 \\
\hline $\mathrm{R}^{2}$ & 0.766 & 0.708 & 0.765 & 0.707 & 0.654 & 0.590 \\
\hline
\end{tabular}


